\title{
AVALIAR OU NÃO AVALIAR, EIS A QUESTÃO: O ESTADO DA ARTE NAS PESQUISAS SOBRE AVALIATIVIDADE EM AUDIODESCRIÇÃO
}

\section{TO APPRAISE OR NOT TO APPRAISE, THAT IS THE QUESTION: THE STATE OF THE ART IN APPRAISAL RESEARCH IN AUDIO DESCRIPTION}

\section{Pedro Henrique Lima Praxedes Filho* Daniel de Albuquerque e Arraes**}

\section{RESUMO}

A Audiodescrição (AD) é, grosso modo, a tradução em palavras das impressões visuais de dado objeto, com o intuito de torná-lo acessível às pessoas com deficiência visual $\left(\mathrm{PcDV}_{\mathrm{s}}\right)$. Consiste não apenas num meio de acessibilidade, mas também numa modalidade de tradução intersemiótica. A literatura não acadêmica sobre $\mathrm{AD}$ tem enfatizado ao longo dos anos a necessidade de o audiodescritor produzir roteiros neutros, de modo a não tirar das $\mathrm{PcDVs}$ a independência para formarem seus próprios juízos de valor; todavia, os defensores deste critério falham em defini-lo a contento ou demonstrar como produzir um roteiro de AD neutro. Nesse sentido, pesquisadores da Universidade Estadual do Ceará vêm realizando pesquisas empíricas com roteiros de $\mathrm{AD}$ para verificar a viabilidade teórica e prática da neutralidade, ancorandose principalmente no arcabouço teórico-metodológico da Linguística Sistêmico-Funcional, e dentro desta, o Sistema de Avaliatividade. O objetivo do presente artigo é apresentar o estado da arte destas pesquisas, relatando o percurso investigativo desde as primeiras pesquisas até o presente.

Palavras-chave: tradução audiovisual acessível; audiodescrição; sistema de avaliatividade.

\section{ABSTRACT}

Audio description (AD) is, broadly speaking, the translation into words of visual impressions from a given object, aiming to make it accessible to the visually impaired. It is not only a means of accessibility, but also a modality of intersemiotic translation. The nonacademic literature on the subject has been emphasizing for many years the need to produce neutral $\mathrm{AD}$ scripts, to avoid interfering in the independence of the visually impaired to make their own judgments. However, supporters of this criterion fail to define it or to demonstrate how to produce a neutral script. Therefore, researchers from the State University of Ceará have been conducting empirical research with $\mathrm{AD}$ scripts to verify both the theoretical as well as

\footnotetext{
* Universidade Estadual do Ceará, Fortaleza, CE. Brasil. pedro.praxedes@uece.br

** Universidade Estadual do Ceará, Fortaleza, CE. Brasil. arraes.d@gmail.com
} 
the practical feasibility of such parameter of neutrality. The research has relied mainly on the theoretical and methodological framework of Systemic-Functional Linguistics, and within it, the Appraisal System. This work aims at presenting the state of the art of such research, reporting the trajectory of investigations from the first works up to present.

Keywords: accessible audiovisual translation; audio description; appraisal system.

\section{INTRODUÇÃO}

A Audiodescrição (AD) é um recurso de acessibilidade audiovisual definido, grosso modo, como "[...] um meio de traduzir a impressão visual de um objeto em

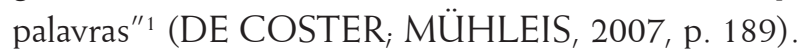

Nos primórdios de seu desenvolvimento, pensava-se a AD apenas em relação à imagem em movimento (cinema e TV), acarretando numa definição de $\mathrm{AD}$ como a utilização dos intervalos entre falas na trilha sonora original de produtos audiovisuais para inserir texto oral contendo traduções das informações visuais ali presentes.

Contudo, tal definição está ultrapassada, haja vista o emprego da AD em inúmeros contextos: em museus ou exposições de arte, tornando acessíveis imagens estáticas, como fotografias, esculturas e pinturas (MAGALHÃES; ARAÚJO, 2012); em livros didáticos digitais, com textos falados e imagens descritas oralmente, ambos através do formato MecDaisy ${ }^{2}$; em exames públicos (como vestibulares, concursos públicos e o Exame Nacional do Ensino Médio (ENEM)), nos quais as pessoas com deficiência visual (PcDVs) podem solicitar um profissional que lhes leia a prova e audiodescreva o que houver de imagens nas questões.

A ampla disseminação da $\mathrm{AD}$ torna premente a pesquisa sobre esta modalidade de tradução, para se estabelecerem sólidos critérios de qualidade que garantam a efetiva inclusão das PcDVs. Neste quesito, a literatura não acadêmica sobre $\mathrm{AD}$ tem postulado que não se deve retirar das $\mathrm{PcDV}$ s a liberdade para construírem, sozinhas, seus juízos de valor acerca do produto (audio)visual. Logo, toda AD deveria ser isenta dos julgamentos valorativos do audiodescritor. Um autor de língua inglesa, inclusive, propõe uma sigla a este respeito: WYSIWYS (What you see is what you say) - em português (o que você vê é o que você diz) (SNYDER, 2008, p. 195-196).

Não há dúvidas de que as $\mathrm{PcDV}$ s são plenamente capazes em suas faculdades cognitivas e emocionais, podendo realizar suas próprias inferências e

1. Esta e todas as demais traduções da língua inglesa para o português são de nossa autoria.

2. Plataforma de digitalização de livros lançada pelo Ministério da Educação brasileiro em parceria com o Núcleo de Computação Eletrônica da Universidade Federal do Rio de Janeiro (NCE/UFRJ). 
juízos. Não obstante, como mostram, por exemplo, Holland (2009) e Praxedes Filho e Magalhães $(2013 ; 2015)$, tal prescrição de neutralidade total pode causar dificuldades na elaboração de roteiros de $\mathrm{AD}$, dado que a literatura não acadêmica falha em explicar de que modo ser neutro.

Com efeito, tanto a carência de diretrizes sobre a produção de roteiros de $\mathrm{AD}$ neutros, quanto a ausência de evidências empíricas de que é possível alcançar tal objetivo, pesam contra a prescrição de neutralidade em AD.

O objetivo deste artigo é apresentar a trajetória de pesquisas realizadas pelo grupo Legendagem e Audiodescrição (LEAD) da Universidade Estadual do Ceará (UECE) sobre AD pelo viés do Sistema de Avaliatividade, este uma parte integrante de uma proposta maior sobre o estudo da língua em uso, a Linguística Sistêmico-Funcional (LSF).

O artigo contém, além desta introdução: uma seção localizando a audiodescrição dentro dos Estudos da Tradução; uma seção apresentando os conceitos básicos relativos ao Sistema de Avaliatividade; uma seção discursando sobre as pesquisas já realizadas pelo grupo LEAD e os resultados alcançados; e uma seção final ponderando sobre futuros desdobramentos sobre a pesquisa em $A D$ via Sistema de Avaliatividade.

\section{TRADUÇÃO AUDIOVISUAL E ACESSIBILIDADE}

A AD é uma das modalidades de tradução estudada pela área disciplinar Tradução Audiovisual (TAV), esta caracterizada pelo trabalho de tradução de textos multimodais - pois conjugam vários modos semióticos (imagem, sons, linguagem verbal, cores e perspectiva) na sua produção e recepção -, e multimidiáticos - haja vista a profusão de suportes de difusão dos textos (INGHILERI, 2009). A TAV, por sua vez, está enquadrada dentro da área maior dos Estudos da Tradução.

Convencionalmente, a TAV é constituída de três modalidades de tradução: a legendagem, o voice-over e a dublagem. Mais recentemente, com o avanço tecnológico e das políticas de empoderamento das minorias, surgiram novas modalidades de TAV: a AD para cegos e pessoas com baixa visão; a legendagem para surdos e ensurdecidos (LSE); e a janela de língua de sinais. Propôs-se, então, que estas três modalidades de TAV constituam uma nova subárea dos Estudos da Tradução: a Tradução Audiovisual Acessível (JIMENEZ, 2010) (sigla brasileira, TAVa (ADERALDO, 2014)).

Tornar algo "acessível" significa garantir condições de igualdade entre as pessoas não apenas em termos físicos - por exemplo, a construção de rampas 
especiais para cadeirantes -, mas também em termos do usufruto, com conforto e segurança, de espaços, serviços e produtos, tanto físicos quanto virtuais, presencialmente ou não. (ALONSO, 2007).

Diante desta concepção mais abrangente de acessibilidade, fica patente a importância de instrumentalizar o audiodescritor para executar a tarefa de apropriarse de um texto de partida constituído pela interação entre diferentes sistemas de signos, e ressignificá-lo para as PcDVs. Remael e Vercauteren (2007) ponderam:

Em alguns países europeus [...] a prática da audiodescrição (AD) está relativamente bem estabelecida [...]. Todavia, nenhuma das diretrizes existentes é ideal como uma ferramenta didática [...]. Os estudantes, [...] precisam de diretivas ou "regras" que os ajudem a tomar decisões [...]. É por isto que algumas das instruções existentes de AD permanecem muito vagas [...], de modo a serem úteis de um ponto de vista didático. (REMAEL; VERCAUTEREN, 2007, p. 74, grifo nosso)

Segundo os autores, de uma maneira geral, as diretrizes de AD podem ser classificadas em quatro categorias: (i) o que audiodescrever?; (ii) quando fazê-lo?; (iii) como fazê-lo?; e (iv) quanto deve ser descrito? (REMAEL; VERCAUTEREN, 2007, p. 75). Com relação ao "como?", uma organização estadunidense, a Audio Description Coallition", no documento Standards for Audio Description and Code of Professional Conduct for Describers (2008), prescreve o seguinte:

Esta é a primeira regra: o que você vê é o que você descreve. Você vê aparências e ações físicas; você não vê motivações ou intenções. Nunca descreva o que você acha que vê. [...]

Permita que os ouvintes formem suas próprias opiniões e cheguem às suas próprias conclusões. $[\ldots]$

Os humores, as razões ou o raciocínio de um personagem não são visíveis e, portanto, não devem ser descritos. [...]

É mais interessante listar os itens que estão em um amontoado de coisas, se o tempo permitir, do que dizer: "o sótão está amontoado" (STANDARDS, 2008, p. 1-3, grifos no original)

Para os Estudos da Tradução, esta passagem é problemática, pois parte do pressuposto de que é possível haver uma correspondência termo a termo entre o mundo físico e as línguas naturais. Jakobson (2000 [1959]), por exemplo, entende que não há relação intrínseca entre signos (no código linguístico) e referentes (no mundo da matéria); o significado de qualquer signo é a sua elaboração, sua explicitação, sua tradução em signo(s) alternativo(s), independente de esta tradução acontecer dentro de uma mesma língua ou entre línguas (ou até mesmo entre meios semióticos diferentes).

Traduzir, portanto, será sempre interpretar, concepção antitética às prescrições de $\mathrm{AD}$ do tipo "[n]ão edite, interprete, explique, analise [...]" (STANDARDS, 
2008, p. 2). A inviabilidade teórica da neutralidade também se reflete no plano prático da AD. Por exemplo, Holland (2009), audiodescritor britânico, questiona a possibilidade de neutralidade em $\mathrm{AD}$ ao comparar seu treinamento e posterior atuação profissional. Inicialmente, ele fora admoestado a não conversar com o diretor ou outros membros das companhias de teatro, sob o pretexto de que "eles te dirão o que querem que você veja" (p. 173, grifo no original). Não obstante, argumenta o autor que um maior conhecimento sobre o objeto da descrição permite selecionar melhor quais informações serão mais relevantes no sentido de dar às PcDVs uma noção global da obra apreciada.

Holland (2009) cita como exemplo, no teatro, uma história infantil como Peter Pan, na qual as personagens têm a capacidade de voar, efeito alcançado na encenação da peça através de cordas e roldanas suspendendo os atores. $\mathrm{O}$ que se vê não são pessoas voando, mas pessoas dependuradas. Caso o audiodescritor se prenda à literalidade das cordas e roldanas, acabará privando o público infantil de PcDVs da magia do teatro, agindo na contramão do que prega a acessibilidade universal tal como conceituada anteriormente (ALONSO, 2007).

Este impasse acarretou em muitas discussões entre os membros do grupo LEAD, tanto os pesquisadores, quanto os audiodescritores, sobre qual decisão tomar a este respeito. Surgiu, então, a proposta de examinar, através de estudos de caso, a presença (ou ausência) de neutralidade em roteiros de AD considerados neutros por seus autores. Para alcançar tais fins, os pesquisadores do grupo LEAD utilizaram como aporte teórico-metodológico a Linguística Sistêmico-funcional (LSF) (HALLIDAY; MATTHIESSEN, 2014) e, dentro dela, o Sistema de Avaliatividade (MARTIN; WHITE, 2005). Esta descrição teórica da avaliação defende que quaisquer enunciados em linguagem verbal (desde aqueles explicitamente opinativos, até aqueles que se pretendem asserções categóricas) estão imersos em intersubjetividade e, portanto, em posicionamentos avaliativos, visto que todo texto é produzido numa situação de interação com algum interlocutor, seja ele real, potencial ou imaginário.

Já que o Sistema de Avaliatividade é o alicerce dos estudos a serem aqui resenhados, faz-se necessário apresentá-lo antes de traçarmos os resultados encontrados pelo grupo LEAD.

\section{0 SISTEMA DE AVALIATIVIDADE}

O Sistema de Avaliatividade (MARTIN, WHITE, 2005; MARTIN, ROSE, 2007) foi desenvolvido com o propósito de analisar a linguagem da avaliação. Isto 
significa dizer que, num nível mais grosseiro, permite modelar como as pessoas expõem linguisticamente: (i) suas atitudes em relação às experiências cotidianas - o que emociona positiva ou negativamente, o que se julga correto ou reprovável, o que se considera belo ou asqueroso -; (ii) seu alinhamento ou desalinhamento com os posicionamentos emitidos por si próprio ou por outrem; (iii) seu modo de graduar as avaliações, ora saturando-as, ora diluindo-as. Porém, num nível mais sutil, permite também vislumbrar os processos de criação, no texto, de uma persona autoral, com o intuito de posicionar os interlocutores de tal maneira a estarem mais suscetíveis aos valores e ideais expostos no texto.

Os proponentes do Sistema de Avaliatividade buscaram edificá-lo com base na LSF (HALLIDAY; MATTHIESSEN, 2014), uma perspectiva funcionalista de estudo das línguas humanas, o que significa que a LSF não se contenta em abordar apenas questões intralinguísticas (dos significados, das formas e dos recursos sonoros e gráficos), mas procura incorporar em seu arcabouço as coerções extralinguísticas (culturais, sociais e ideológicas) que se impõem ao uso espontâneo da língua pelas pessoas do mundo real.

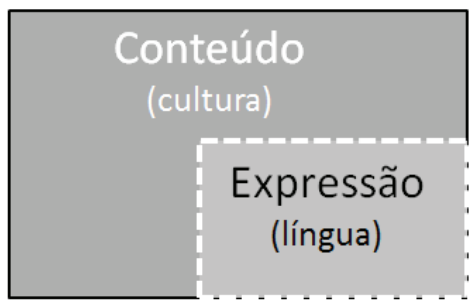

Figura 1. Tensão dialética entre cultura e língua

Fonte: nossa autoria

Estabelece-se, assim, uma tensão dialética entre cultura e língua, como mostra a Figura 1: por um lado, a cultura (conteúdo) ativa o sistema linguístico (expressão), por outro lado, a língua constrói a cultura. É devido a esta perspectiva que o fundador da LSF denominou sua abordagem de estudo das diversas linguagens de Semiótica Social (HALLIDAY, 1978). Segundo esta abordagem, a língua (ou qualquer outra linguagem) é um potencial de recursos voltado para a construção de sentido via textos, sempre enunciados em situações autênticas de interação humana, em suporte oral ou escrito (ou sinalizado, no caso das línguas de sinais).

A LSF postula que as línguas naturais humanas diferem da linguagem de outras espécies pela sua capacidade de sobrepor diferentes tipos de significados num mesmo enunciado. Haveria, então, três áreas de significados ou metafunções: (i) a metafunção ideacional, responsável por representar discursivamente as experiências 
cotidianas humanas, tanto interiores, quanto exteriores; (ii) a metafunção interpessoal, responsável pela negociação e troca entre sujeitos destas experiências cotidianas; e (iii) a metafunção textual, responsável por viabilizar as negociações e trocas de experiências representadas através da elaboração de textos coesos e coerentes.

Outro legado importante da Semiótica Social de Halliday (1978), complementar à tripartição dos significados acima descrita, é a estratificação do sistema linguístico em níveis ou estratos: o estrato dos significados (ou semântica discursiva), que é realizado pelo estrato das formas (ou lexicogramática), que é realizado pelos recursos sonoros (ou fonologia).

$\mathrm{Na}$ LSF, a maneira clássica de representar visualmente a complementaridade entre estratos da língua e metafunções pode ser observada na Figura 2, na qual a estratificação é representada pelos três círculos que se tocam num mesmo ponto tangencial - o círculo menor representando a fonologia; o círculo intermediário, a lexicogramática; e o círculo maior, a semântica discursiva -, ao passo que as três metafunções são representadas pelas três áreas do círculo mais externo e que se irradiam para os círculos menores.

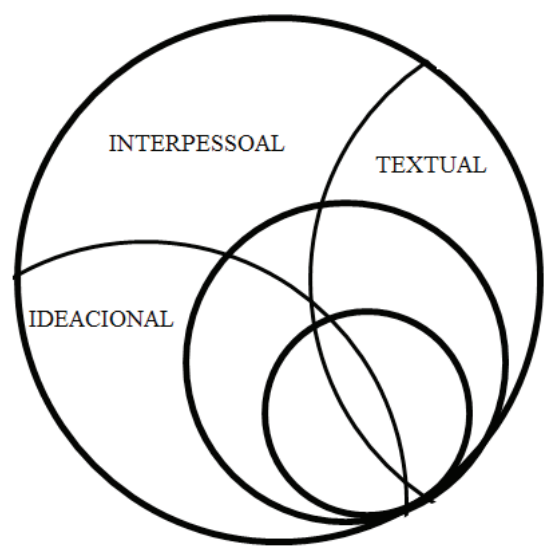

Figura 2. Complementaridade entre estratos e metafunções na LSF Fonte: adaptada de Martin e White (2005)

Em cada estrato estão alocados os potenciais de recursos disponibilizados ao usuário da língua para construção de sentido via texto. Estes potenciais de recursos são representados na LSF através de sistemas organizados em redes de sistemas, como exemplifica a Figura 3, em relação ao Sistema de Avaliatividade, que na verdade, então, é um sistema de sistemas ou um polissistema, localizado no estrato da semântica, especificamente dentro da metafunção interpessoal. 


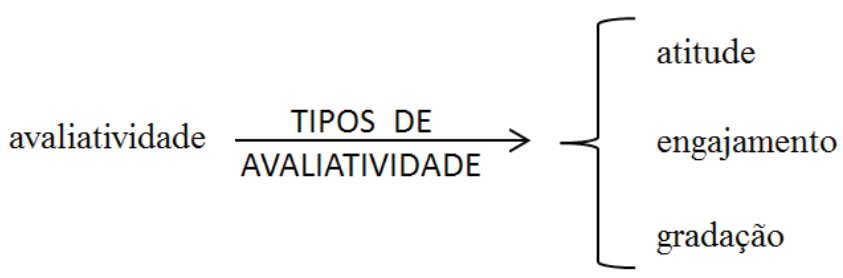

Figura 3. Representação abreviada do sistema de AVALIATIIIDADE Fonte: adaptada de Martin e White (2005) e Martin e Rose (2007)

É a partir da ideia de redes de sistemas que é possível pensar a língua não como um sistema de regras, mas como escolhas sistêmicas, escolhas feitas percorrendo-se as redes de sistema. Construir um texto verbal, portanto, significa fazer escolhas dentro das diversas redes de sistemas que constituem dado sistema linguístico, dentre elas, a rede de sistemas de AVALIATIVIDADE ${ }^{4}$.

Estas escolhas sistêmicas sempre se iniciam a partir de uma dada condição de entrada: no caso dos significados avaliativos, a condição de entrada é o termo 'avaliatividade', na extremidade esquerda da Figura 3. A ativação de uma condição de entrada disponibiliza ao usuário da língua escolhas mais refinadas, detalhadas, delicadas: a ativação do termo 'avaliatividade' nos leva ao sistema à direita TIPOS DE AVALIATIVIDADE, Composto por três termos mais delicados, 'atitude', 'engajamento' e 'gradação'.

Antes de detalharmos os três tipos de avaliações, é preciso esclarecer que a rede de sistemas de AVALIATIVIDADE não será aqui descrito em sua inteireza, devido às limitações de espaço, mas apenas até o segundo nível de delicadeza. Tendo dito isso, passemos à explanação da rede.

\subsection{Atitude}

O primeiro tipo de significado avaliativo é 'atitude', que diz respeito à expressão de sentimentos, como no exemplo (1), célebre frase do político brasileiro Ulysses Guimarães (1916-1992):

(1) Temos ódio à ditadura. Ódio e nojo. Amaldiçoamos a tirania aonde quer que ela desgrace homens e nações. (CÂMARA, 2006)

4. Na LSF, convencionou-se que o nome de um sistema deve ser grafado com letras maiúsculas, enquanto o nome de um termo (escolha) dentro do sistema deve ser grafado em letras minúsculas e, quando mencionado no corpo de um texto, o nome do termo deve vir entre aspas simples. 
No dia 5 de outubro de 1988, quando foi promulgada a primeira Constituição democrática brasileira após vinte e quatro anos de ditadura militar, Ulysses Guimarães, então presidente da Assembleia Nacional Constituinte, discursou durante a cerimônia de promulgação da nova Carta Magna. Guimarães, através do trecho exemplificado em (1), instala em seu texto um posicionamento atitudinal de desdém e indignação em relação ao regime político anterior. Trata-se de uma postura atitudinal negativa em relação ao totalitarismo de maneira geral, e aos governos militares brasileiros em particular, postura esta resultante das escolhas sistêmicas realizadas na subrede de 'atitude', melhor detalhada na Figura 4.

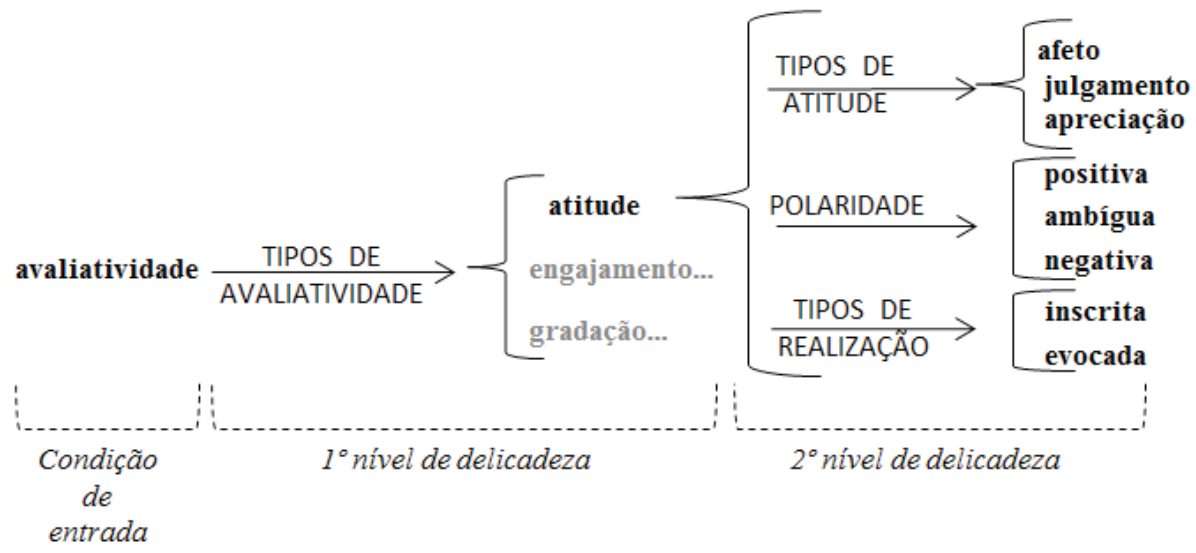

Figura 4. Subrede de 'atitude' até o $2^{\circ}$ nível de delicadeza Fonte: adaptada de Martin e White (2005), Martin e Rose (2007) e Bednarek (2008)

A subrede de 'atitude' possui, no seu $2^{\circ}$ nível de delicadeza (vide Figura 4), três sistemas simultâneos ${ }^{5}$ : o sistema TIPOS DE ATITUDE, o sistema POLARIDADE e o sistema TIPOS DE REALIZAÇÃO. O primeiro destes, TIPOS DE ATITUDE, leva a possíveis escolhas de três tipos de significados relacionados aos sentimentos:

I 'afeto', que diz respeito à expressão de sentimentos emocionais, pulsivos, ou seja, aos "assuntos do coração", tal como podemos observar no trecho (1) do

5. Outra convenção utilizada na LSF é que termos ou sistemas que possam ser escolhidos simultaneamente devem ser abarcados por uma chave (como no caso do termo 'atitude', a partir do qual uma chave à direita envolve três sistemas), ao passo que termos ou sistemas que devam ser mutuamente excludentes precisam estar envoltos por um colchete (como no caso do sistema POLARIDADE, à direita do qual há uma chave englobando os termos 'positiva', 'ambígua' e 'negativa'). 
discurso de Ulysses Guimarães pelo uso dos substantivos [ódio] e [nojo] e do verbo [Amaldiçoamos];

II 'julgamento', que diz respeito à expressão de sentimentos morais e éticos, tal como podemos observar no uso de [tirania] e [desgrace] no trecho (1), palavras que reprovam as condutas assumidas pelo regime militar; $\mathrm{e}$

III 'apreciação', que diz respeito à expressão de opiniões estéticas sobre fenômenos naturais ou semióticos alinhadas ao valor destes num dado campo, opiniões estas que não estão presentes no trecho (1), mas que podem ser exemplificadas pelo trecho (2).

(2) Brasil, um sonho intenso, um raio vívido

De amor e de esperança à terra desce

Se em teu formoso céu, risonho e límpido

A imagem do cruzeiro resplandece (BRASIL, 1922)

Neste trecho de nosso Hino Nacional, o autor, Joaquim Osório Duque Estrada (1870-1927), exalta o Brasil através dos recursos avaliativos de 'apreciação' aplicados a figuras de linguagem: é feita uma analogia entre o país e [um sonho], apreciado como [intenso]; a nação é comparada a [um raio], apreciado como [vívido].

Passemos agora à discussão dos outros dois sistemas dos significados atitudinais, POLARIDADE e TIPOS DE REALIZAÇÃO. O primeiro sistema responde pelo fato de as avaliações atitudinais operarem ao longo de uma escala entre os polos positivo e negativo - no trecho (1), Ulysses Guimarães declara ter [ódio e nojo] à ditadura, um exemplo de 'afeto' negativo; porém, mais adiante no seu discurso, Guimarães avalia positivamente a Constituição de 1988, como mostra o trecho (3).

(3) Não é a Constituição perfeita, mas será útil, pioneira, desbravadora, será luz ainda que de lamparina na noite dos desgraçados. (CÂMARA, 2006)

Ao caracterizar a Constituição como [útil], [pioneira] e [desbravadora], Guimarães instaura em seu discurso avaliações atitudinais positivas de 'julgamento'.

Além de salientar as avaliações positivas e negativas, é importante salientar os achados de Bednarek (2008), que através de uma ampla pesquisa via Linguística de Corpus em língua inglesa, encontrou casos de avaliações atitudinais ambivalentes, não podendo ser enquadradas nos polos positivo ou negativo, daí a proposta da autora de incluir, no sistema POLARIDADE, atitudes neutras (denominada no presente trabalho de atitude 'ambígua' (vide Figura 4)).

O último sistema a ser discutido na subrede de 'atitude' é o de TIPOS DE REALIZAÇÃO. As avaliações atitudinais podem ser comunicadas ora explicitamente - 
como no caso dos trechos (1), (2) e (3) (atitude 'inscrita') -, ora implicitamente, como no trecho (4):

(4) No meio do cômodo estava Lisavieta em pé, com uma trouxa grande na mão, olhando pasma para a irmã morta, inteiramente branca como um pano e como que sem forças para gritar. [...] ela começou a tremer feito vara verde, $[\ldots]$ rosto convulsionado, $[. .$.$] fez menção de abrir a boca, mas mesmo assim não$ gritou [...] como se lhe faltasse ar para tanto. (DOSTOIÉVSKI, 2009 [1866], p. 93-94, grifos nossos).

Neste trecho da obra Crime e Castigo, de Dostoiévski (2009 [1866]), Lisavieta entra no apartamento de sua irmã, Aliena Ivánovna, e encontra seu cadáver ensanguentado estirado no chão, assassinada pelo protagonista, Raskolnikov. No texto, a primeira avaliação de Lisavieta é 'inscrita', marcada explicitamente pela palavra [pasma $;$; porém, no desenrolar da cena, a descrição avaliativa da personagem é 'evocada'; a descrição de suas reações físicas (em itálico no trecho (4)) deixa transparecer, implicitamente, seu estado emocional.

Terminada a descrição da subrede de 'atitude', passemos agora à explanação da subrede de 'engajamento'.

\subsection{Engajamento}

Além de avaliações atitudinais, também se pode avaliar via 'engajamento', ou seja, permitindo ou não que outras vozes sociais se manifestem no texto para, então, se alinhar a elas ou se contrapor a elas, como é o caso do trecho (5) do discurso de Ulysses Guimarães:

(5) A Constituição certamente não é perfeita. Ela própria o confessa ao admitir a reforma. (CÂMARA, 2006)

A palavra [certamente] no trecho (5), num primeiro plano, deixa transparecer a convicção do enunciador em relação à imagem representada no trecho - de que a Constituição não é perfeita. Porém, num plano sutil, entra em funcionamento outro mecanismo intersubjetivo: o enunciador cria para si um público idealizado que compartilha de seus pontos de vista irrestritamente, ancorando-se numa suposta obviedade do que foi representando linguisticamente, a tal ponto de o próprio texto constitucional admiti-lo.

O trecho (5) exemplifica o chamado engajamento por 'heteroglossia' (vide Figura 5), no qual se abre espaço para que a dialogia ${ }^{6}$ constitutiva de todo e qualquer discurso venha à tona na superfície do texto. A 'heteroglossia' é um dos dois termos

6. A subrede de 'engajamento' foi elaborada a partir do conceito de dialogismo elaborado por Mikhail Bakhtin e seus companheiros. 
mutuamente excludentes ${ }^{7}$ do sistema TIPOS DE ENGAJAMENTO, juntamente ao termo 'monoglossia'.

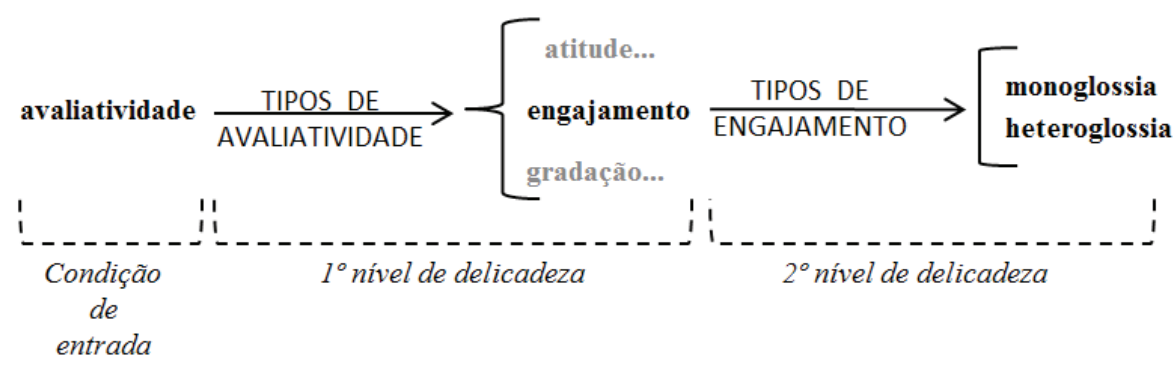

Figura 5. Subrede de 'engajamento' até o $2^{\circ}$ nível de delicadeza

Fonte: adaptada de Martin e White (2005), Martin e Rose (2007)

De uma maneira geral, a 'monoglossia' diz respeito a asserções categóricas que não permitem questionamento ou que não dão margem à dialogia; "a asserção categórica está geralmente associada com conhecimento consensual, versões de eventos que são vistas como fatos [...], no geral, "conhecidas" ou "aceitas" no contexto comunicativo" (WHITE, 2003, p. 263). Para aclarar estas ideias, examinemos o trecho (6), retirado da fala do Deputado Jair Bolsonaro durante sessão plenária da Câmara dos Deputados do dia 01 de Abril de 2015.

(6) Senhor presidente, é um assunto que eu esperava não tocar mais nele [sic], mas eu tenho uma convicção: uma célula está para um corpo, assim como a família está para a sociedade. Uma célula doentia, corpo doente. Uma familia saudável, Estado forte. (PARLATUBEBRASIL, 2015, grifo nosso)

O "assunto" mencionado pelo Deputado é a inserção de discussões sobre diversidade sexual nos materiais didáticos de escolas públicas. No trecho (6), o destaque em itálico mostra como o Deputado constrói discursivamente a relação entre o Estado e a instituição familiar comparando-a com a relação entre o corpo de um ser vivo com suas células, tal que o funcionamento errático das partes (família/ célula) debilita o todo (Estado/corpo).

Porém, o mais importante a se notar é como esta analogia é organizada lexicogramaticalmente via asserções categóricas, no sentido de que sequer é necessário construir linguisticamente uma obviedade. O Deputado está tão convicto da verdade do que diz que sequer precisa estabelecer um entrosamento com seu público via recursos avaliativos explícitos. A simples alusão aos valores e

7. Vide nota de rodapé 5 . 
crenças defendidos pelo Deputado através de palavras como [família] e [Estado] já é suficiente para garantir a adesão de seus interlocutores em potencial. A obviedade, na visão do Deputado, chega a tal ponto que ele sequer precisa explicitar a ligação entre [célula doentia] e [corpo doente] através de um grupo verbal, que está elidido, fazendo-o apenas através da pontuação, operando da mesma forma ao comparar a saúde da família com a fortaleza do Estado.

Ou seja, não são quaisquer asserções categóricas que irão configurar um engajamento por monoglossia, mas aquelas asserções categóricas que operam "frequentemente (e talvez tipicamente) onde há a pressuposição de uma convergência ontológica, axiológica ou epistêmica entre a voz textual e o público" (WHITE, 2003, p. 263).

Passemos agora à discussão do último dos três recursos avaliativos: a gradação.

\subsection{Gradação}

As avaliações humanas podem variar de intensidade; ora são difusas e brandas, ora são intensas e arrebatadoras. Esta escalabilidade se reflete na linguagem da avaliação graças ao potencial de recursos disponibilizado aos usuários de uma língua através da subrede de 'gradação'. Vejamos o trecho (7), outra passagem do clássico de Dostoiévski:

(7) Estava tão malvestido que outra pessoa [...] teria vergonha de sair à rua de dia em semelhantes andrajos. (DOSTOIÉVSKI, 2009 [1866], p. 20, grifo nosso)

No trecho (7), a voz do narrador descreve para o leitor o personagem Raskolnikov, protagonista da obra Crime e Castigo, explicitando uma avaliação atitudinal de apreciação, intensificada pelo advérbio [tão]. Todavia, não se deve achar que as gradações de avaliações são comunicadas apenas por meio de uma palavra em separado ou isolada, como pode ser visto no trecho (8).

(8) O cheiro insuportável das tavernas [...] e os bêbados [...] completavam o colorido repugnante e triste do quadro. (DOSTOIÉVSKI, 2009 [1866], p. 20, grifo nosso)

A palavra [insuportável] no trecho (8) põe o cheiro numa escala de intensidade que está inserida (ou fusionada) nela mesma, quando comparada com outras palavras do mesmo campo semântico, como exemplifica a Figura 6. 
\begin{tabular}{l|l} 
Cheiro ameno & - INTENSO \\
Cheiro desagradável & \\
Cheiro horrível & \\
Cheiro insuportável & $\downarrow+$ INTENSO
\end{tabular}

Figura 6. Gradação fusionada de sentimentos

Fonte: nossa autoria

Estes aumentos de intensidade de sentimentos (atitude) nos trechos (7) e (8) são exemplos de avaliação graduadora por 'força', termo do sistema TIPOS DE GRADAÇÃO, como mostra a Figura 7.

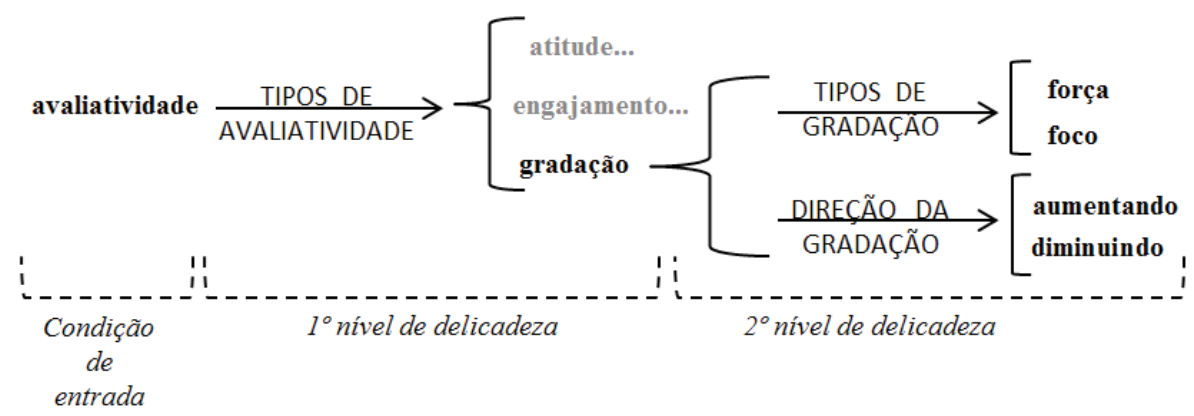

Figura 7. Subrede de 'gradação' até o $2^{\circ}$ nível de delicadeza

Fonte: adaptada de Martin e White (2005), Martin e Rose (2007)

O sistema TIPOS DE GRADAÇÃO, simultâneo ao sistema DIREÇÃO DA GRADAÇÃO (vide Figura 7), ainda prevê outro tipo de ajuste avaliativo pela voz textual, quando se quer regular a representatividade de dado objeto frente à categoria em que está inserido. Vejamos o trecho (9).

(9) A cachaça pode, diferentemente do uísque, da tequila e do rum, ser armazenada em vários tipos de madeira, que dão coloração e gosto característico à bebida. Essa diversidade é o grande diferencial do produto tipicamente brasileiro e, geralmente, define as características regionais. (PERUCCI, 2016, grifo nosso)

O fraseado em itálico no trecho (9) avalia a cachaça como um objeto muito representativo da categoria 'coisas brasileiras', ou seja, gradua-se a cachaça por 'foco', na direção 'aumentando'. Tal como as gradações por 'força', as gradações por 'foco' tanto podem aumentar, quanto diminuir. 
Findada a exposição do Sistema de Avaliatividade, podemos finalmente descrever o percurso investigativo realizado pelo grupo LEAD sobre o problema da neutralidade em AD.

\section{AS PESQUISAS DE AVALIATIVIDADE EM AD}

\subsection{As primeiras pesquisas}

As pesquisas em AD envolvendo o Sistema de Avaliatividade e a LSF se iniciaram por ocasião da cooperação interinstitucional entre a UECE e a Universidade Federal de Minas Gerais (UFMG), durante o quinquênio 2007-2011, através do edital PROCAD CAPES 008/2007. Naquele período, o autor principal deste artigo foi convidado a participar daquele projeto realizando uma pesquisa sobre o critério da neutralidade em AD. Disto resultaram as publicações de Praxedes Filho e Magalhães $(2013$; 2015), ambas trabalhando com roteiros de AD de pinturas. No primeiro trabalho, os autores (PRAXEDES FILHO; MAGALHÃES, 2013) analisaram, quanto à neutralidade, seis roteiros ${ }^{8}$ de $\mathrm{AD}$ de pinturas em língua inglesa elaborados por defensores da neutralidade e, àquela época, disponibilizados online pela Audio Description Coallition.

O objetivo da pesquisa era verificar se os roteiros eram ou não neutros, logo, a categorização dos dados se deu apenas até o $2^{\circ}$ nível de delicadeza e, na subrede de 'atitude', trabalhou-se apenas com o sistema TIPOS DE ATITUDE. Para alcançar esta meta, Praxedes Filho e Magalhães (2013) estabeleceram as seguintes diretrizes metodológicas: (i) os roteiros só seriam considerados neutros se possuíssem $0 \%$ de avaliações, seja de 'atitude', seja de 'engajamento', seja de 'gradação'; (ii) nem todas as asserções categóricas seriam consideradas instâncias de 'monoglossia' (considerando que todos os textos têm orações sem marcas de modalização, se qualquer oração categórica fosse enquadrada como um caso de 'monoglossia', haveria um enviesamento dos dados e, consequentemente, todos os roteiros seriam avaliativos). A categorização dos dados a partir do Sistema de Avaliatividade foi realizada manualmente.

Foram analisados os roteiros das seguintes pinturas, todos acessados em 16/10/2011 (PRAXEDES FILHO; MAGALHÃES, 2013, p. 79):

1 The Bather, de Paul Cézanne;

2 Convergence, de Jackson Pollock;

8. Os pesquisadores analisaram seis roteiros de $\mathrm{AD}$ retirados do site: http://www.artbeyondsight.org/. 
3 Girl with a Mandolin, de Pablo Picasso;

4 View of Cadadues with Shadow of Mount Pani, de Salvador Dali;

5 The Adoration of the Magi, de Andrea Mantegna; e

6 Woman 1, de Willem de Kooning.

Os autores dos seis roteiros de $\mathrm{AD}$ em língua inglesa, a partir do critério metodológico estabelecido, não alcançaram o objetivo de neutralidade, como mostra a Tabela 1.

Tabela 1. Ocorrências avaliativas em inglês no $1^{\circ} \mathrm{e} 2^{\circ}$ níveis de delicadeza

\begin{tabular}{|c|c|c|c|c|c|c|c|}
\hline & \multicolumn{3}{|c|}{ ATITUDE } & \multicolumn{2}{|c|}{ ENGAJ. } & \multicolumn{2}{|c|}{ GRAD. } \\
\hline Roteiro 1 & \multicolumn{3}{|c|}{$27,1 \%$} & \multicolumn{2}{|c|}{$15,3 \%$} & \multicolumn{2}{|c|}{$57,6 \%$} \\
\hline Roteiro 2 & \multicolumn{3}{|c|}{$24,2 \%$} & \multicolumn{2}{|c|}{$22,4 \%$} & \multicolumn{2}{|c|}{$53,4 \%$} \\
\hline Roteiro 3 & \multicolumn{3}{|c|}{$32,0 \%$} & \multicolumn{2}{|c|}{$16,0 \%$} & \multicolumn{2}{|c|}{$52,0 \%$} \\
\hline Roteiro 4 & \multicolumn{3}{|c|}{$19,0 \%$} & \multicolumn{2}{|c|}{$19,0 \%$} & \multicolumn{2}{|c|}{$62,0 \%$} \\
\hline Roteiro 5 & \multicolumn{3}{|c|}{$50,0 \%$} & \multicolumn{2}{|c|}{$6,6 \%$} & \multicolumn{2}{|c|}{$43,4 \%$} \\
\hline Roteiro 6 & \multicolumn{3}{|c|}{$19,0 \%$} & \multicolumn{2}{|c|}{$13,8 \%$} & \multicolumn{2}{|c|}{$67,2 \%$} \\
\hline & Afeto & Julgamento & Apreciação & Mono & Heter. & Força & Foco \\
\hline Roteiro 1 & $3,4 \%$ & $1,7 \%$ & $22,0 \%$ & $0,0 \%$ & $15,3 \%$ & $37,3 \%$ & $20,3 \%$ \\
\hline Roteiro 2 & $1,7 \%$ & $5,2 \%$ & $17,3 \%$ & $0,0 \%$ & $22,4 \%$ & $51,7 \%$ & $1,7 \%$ \\
\hline Roteiro 3 & $2,0 \%$ & $10,0 \%$ & $20,0 \%$ & $0,0 \%$ & $16,0 \%$ & $42,0 \%$ & $10,0 \%$ \\
\hline Roteiro 4 & $9,6 \%$ & $0,0 \%$ & $9,6 \%$ & $0,0 \%$ & $19,0 \%$ & $57,2 \%$ & $4,6 \%$ \\
\hline Roteiro 5 & $10,5 \%$ & $1,7 \%$ & $36,9 \%$ & $0,0 \%$ & $6,6 \%$ & $38,1 \%$ & $5,2 \%$ \\
\hline Roteiro 6 & $1,7 \%$ & $2,7 \%$ & $15,5 \%$ & $0,0 \%$ & $13,8 \%$ & $58,6 \%$ & $8,7 \%$ \\
\hline
\end{tabular}

Fonte: adaptada de Praxedes Filho e Magalhães (2013, p. 80)

Como se pode observar na Tabela 1, a incidência de 'engajamento' foi a menos expressiva, variando entre $6,6 \%$ e $22,4 \%$, valores baixos se comparados com a incidência de avaliações por 'gradação', categoria mais expressiva, cujo valores variaram entre $43,4 \%$ e $67,2 \%$. Numa posição intermediária, portanto, ficaram as avaliações atitudinais, variando entre $19 \%$ e $50 \%$.

No âmbito dos significados atitudinais, considerando os critérios metodológicos estipulados, a única ausência de avaliação se deu no roteiro 4 e, assim mesmo, apenas na categoria 'julgamento'. Em todos os outros roteiros, houve incidência dos três tipos de sentimentos, com predominância da categoria 'apreciação', variando entre 9,6\% e 36,9\%. A maior incidência de 'apreciação' faz 
sentido se pensarmos que os roteiros estão avaliando obras de arte, que por natureza intentam provocar um enlevo estético no observador.

No âmbito dos significados de 'engajamento', não houve a incidência de posicionamentos por 'monoglossia', pois não foram encontradas asserções categóricas cujo contexto transparecesse convergência nas visões de mundo dos interlocutores (vide seção 3.2 sobre 'engajamento'); porém, houve ocorrências de posicionamentos heteroglóssicos, variando entre $6,6 \%$ e $22,3 \%$.

Finalmente, no âmbito dos significados de 'gradação', houve grande proeminência de intensificação por 'força', com ocorrências variando entre $37,3 \% \mathrm{e}$ $58,6 \%$, preponderância esta coerente com a maior incidência de 'atitude-apreciação', visto que significados estéticos podem ser graduados.

Passando agora ao segundo estudo de Praxedes Filho e Magalhães (2015), foram analisados seis roteiros de $\mathrm{AD}$ de pinturas elaborados agora em língua portuguesa. Os roteiros foram coletados do periódico online Revista Brasileira de Tradução Visual ${ }^{9} \mathrm{e}$ descrevem as seguintes pinturas (PRAXEDES FILHO, MAGALHÃES, 2015, p. 112):

1 A refeição do bomem cego, de Pablo Picasso;

2 Favela, de Orlando Teruz;

3 'Sem título' da série "Olhos que não querem ver", de Alexandre Silva dos Santos Filho; 4 Uma tela de Esref Armagan;

5 O violeiro, de José Ferraz de Almeida Júnior;

6 Duas mulheres correndo na praia, de Pablo Picasso.

Foram mantidos aqui os critérios metodológicos utilizados em Praxedes Filho e Magalhães (2013). Mais uma vez, apesar de os autores considerarem neutros os seus roteiros, foram encontradas avaliações atitudinais, éticas e estéticas nos roteiros, conforme mostra a Tabela 2 .

Tabela 2. Ocorrências avaliativas nos roteiros de pinturas em português no $1^{\circ}$ e $2^{\circ}$ níveis de delicadeza

\begin{tabular}{|l|c|c|c|}
\hline & ATITUDE & ENGAJ. & GRAD. \\
\hline Roteiro 1 & $27,8 \%$ & $0,0 \%$ & $72,2 \%$ \\
\hline Roteiro 2 & $21,4 \%$ & $0,0 \%$ & $78,6 \%$ \\
\hline
\end{tabular}

9. No período da escrita do presente artigo (maio de 2017), a Revista Brasileira de Tradução Visual estava hospedada num endereço eletrônico diferente daquele a partir do qual o corpus foi coletado. O endereço que consultamos presentemente é: http://audiodescriptionworldwide.com/rbtv/. 


\begin{tabular}{|c|c|c|c|c|c|c|c|}
\hline Roteiro 3 & \multicolumn{3}{|c|}{$15,5 \%$} & \multicolumn{2}{c|}{$20,0 \%$} & \multicolumn{2}{c|}{$64,5 \%$} \\
\hline Roteiro 4 & \multicolumn{3}{|c|}{$8,7 \%$} & \multicolumn{2}{|c|}{$0,0 \%$} & \multicolumn{2}{c|}{$91,3 \%$} \\
\hline Roteiro 5 & \multicolumn{3}{|c|}{$37,5 \%$} & \multicolumn{2}{c|}{$12,5 \%$} & \multicolumn{2}{c|}{$50,0 \%$} \\
\hline Roteiro 6 & \multicolumn{3}{|c|}{$22,7 \%$} & \multicolumn{2}{c|}{$9,1 \%$} & \multicolumn{2}{c|}{$68 \%$} \\
\hline & Afeto & Julgamento & Apreciação & Mono & Heter. & Força & Foco \\
\hline Roteiro 1 & $5,6 \%$ & $0,0 \%$ & $22,2 \%$ & $0,0 \%$ & $0,0 \%$ & $61,1 \%$ & $11,1 \%$ \\
\hline Roteiro 2 & $3,6 \%$ & $0,0 \%$ & $17,8 \%$ & $0,0 \%$ & $0,0 \%$ & $78,6 \%$ & $0,0 \%$ \\
\hline Roteiro 3 & $0,0 \%$ & $2,2 \%$ & $13,3 \%$ & $0,0 \%$ & $20,0 \%$ & $44,5 \%$ & $20,0 \%$ \\
\hline Roteiro 4 & $0,0 \%$ & $0,0 \%$ & $8,7 \%$ & $0,0 \%$ & $0,0 \%$ & $78,3 \%$ & $13,0 \%$ \\
\hline Roteiro 5 & $4,2 \%$ & $0,0 \%$ & $33,3 \%$ & $8,3 \%$ & $4,2 \%$ & $41,7 \%$ & $8,3 \%$ \\
\hline Roteiro 6 & $4,5 \%$ & $4,5 \%$ & $13,7 \%$ & $9,1 \%$ & $0,0 \%$ & $68,2 \%$ & $0,0 \%$ \\
\hline
\end{tabular}

Fonte: adaptada de Praxedes Filho e Magalhães (2015, p. 114-121)

A categoria de engajamento foi a menos expressiva, com ocorrências variando entre $9,1 \%$ e $20 \%$, porém com um diferencial significativo entre roteiros brasileiros e estadunidenses: em três roteiros em português não houve qualquer ocorrência de posicionamentos por 'engajamento'; além disso, os significados de 'gradação' também foram os mais predominantes; porém, nos roteiros brasileiros a quantidade desta categoria variou entre $50 \%$ e $91,3 \%$, um pico bastante superior ao pico de 'gradação' nos roteiros estadunidenses $(67,2 \%)$. Por fim, quanto aos resultados intermediários, os roteiros brasileiros seguiram a mesma tendência da pesquisa com roteiros em inglês: a ocorrência de significados atitudinais no corpus em português teve uma variação entre $8,7 \%$ e $37,5 \%$.

Considerando o segundo nível de delicadeza de 'atitude', houve maior incidência de 'apreciação' (variando entre $8,7 \%$ e 33,3\%), à semelhança do que aconteceu com os roteiros em inglês, ressaltando-se uma ocorrência muito baixa (às vezes nula) de 'afeto' e 'julgamento' nos roteiros nacionais.

Considerando o segundo nível de delicadeza de 'engajamento', a ocorrência de 'heteroglossia' nos roteiros em português foi muito inferior se comparada aos roteiros americanos, chegando inclusive a $0 \%$ nos roteiros 1, 2, 4 e 6 . Inversamente, nos roteiros brasileiros houve incidência de asserções categóricas consideradas por Praxedes Filho e Magalhães exemplos de posicionamentos monoglóssicos: por um lado, ocorreram asserções categóricas que descreviam dado aspecto da pintura em desacordo com o que de fato fora pintado, e por outro lado, ocorreram asserções categóricas que descreviam dado aspecto da pintura extrapolando o que de fato fora pintado. Vejamos alguns exemplos no Quadro 1: 
Quadro 1. exemplos de 'monoglossia' nos roteiros de AD de pinturas em português

\begin{tabular}{|l|l|l|}
\hline \multicolumn{1}{|c|}{ ROTEIRO } & \multicolumn{1}{|c|}{ TRECHO } & \multicolumn{1}{|c|}{ AVALIAÇÃO } \\
\hline 5) O violeiro & $\begin{array}{l}\text { Do batente para cima a parede } \\
\text { está rebocada e pintada com } \\
\text { cor amarela. }\end{array}$ & $\begin{array}{l}\text { Engajamento-monoglossia } \\
\text { (a parede tem áreas sem reboco do batente para } \\
\text { cima })\end{array}$ \\
\hline $\begin{array}{l}\text { 6) Duas mulheres } \\
\text { correndo na praia }\end{array}$ & $\begin{array}{l}\text { Ao fundo, o azul do mar calmo } \\
\text { se une ao azul do céu com nu- } \\
\text { vens carneiras. }\end{array}$ & $\begin{array}{l}\text { Engajamento-monoglossia } \\
\text { (o modo como o pintor representou o mar não permi- } \\
\text { te que se diga que está calmo ou agitado) }\end{array}$ \\
\hline
\end{tabular}

Fonte: Praxedes Filho e Magalhães (2015, p. 120)

O primeiro exemplo do Quadro 1 é um trecho encontrado no roteiro de $\mathrm{AD}$ da pintura 'O violeiro' e descreve uma parede como toda rebocada, quando a pintura apresenta áreas sem reboco. Este tipo de asserção monoglóssica em desacordo com a expressão não verbal foi denominado por Praxedes Filho e Magalhães (2015) de desvio descritivo categórico. Já o segundo exemplo do Quadro 1 foi retirado do roteiro da pintura 'Duas mulheres correndo na praia' e descreve o mar como se fora calmo, sem que a pintura dê subsídios para que o audiodescritor faça tal inferência. Este tipo de asserção linguística monoglóssica com descrição extrapolada em relação à expressão não verbal foi denominado de inferência descritiva categórica.

Finalmente, considerando o segundo nível de delicadeza de 'gradação', os roteiros em português fizeram bastante uso da intensificação por 'força', até mais que os roteiros em inglês, com ocorrências variando entre $41,7 \%$ (roteiro 5) e $78,6 \%$ (roteiro 2 ).

De uma maneira geral, os padrões encontrados nos roteiros em português seguiram uma tendência semelhante à dos roteiros em língua inglesa, com predominância de avaliações de 'gradação-força' em primeiro lugar, seguidas de avaliações de 'atitude-apreciação', com o diferencial de que a discrepância entre 'força' e 'apreciação' em português foi muito maior que em inglês.

Os dois estudos de Praxedes Filho e Magalhães $(2013$; 2015) foram capazes de desmistificar o critério da neutralidade, mostrando empiricamente que, mesmo roteiros de $\mathrm{AD}$ elaborados pelos defensores deste critério, possuem marcas avaliativas. Ademais, os resultados apontaram na direção de um padrão avaliativo nos roteiros de $\mathrm{AD}$ de pinturas. Porém, o corpus analisado foi diminuto, impedindo maiores generalizações, logo, demandando um número maior de pesquisas para se chegar a dados mais conclusivos. Nesse sentido, o grupo LEAD deu continuidade às pesquisas de avaliatividade em $\mathrm{AD}$. 


\subsection{A neutralidade em AD de filmes}

$\mathrm{Na}$ esteira das pesquisas iniciadas pela cooperação UECE-UFMG, outras pesquisas investigaram o parâmetro da neutralidade, porém agora no contexto da $\mathrm{AD}$ de filmes, modalidade que difere da $\mathrm{AD}$ de pinturas: o roteiro voltado para pinturas sofre coerções do texto de partida não verbal no seu conteúdo, mas não na sua expressão, ou seja, os roteiros de pinturas são textos corridos em prosa; já o roteiro voltado para filmes sofre coerções do texto de partida não verbal tanto no seu conteúdo, quanto na sua expressão, consistindo de orações e complexos oracionais curtos inseridos nos intervalos entre as falas dos personagens do filme.

Nesta nova modalidade, houve três pesquisas: Silva (2014; PRAXEDES FILHO; SILVA, 2014), Almeida (2015) e Oliveira Junior e Praxedes Filho (2016). Um diferencial metodológico destas pesquisas foi a incorporação dos métodos da Linguística de Corpus, pela utilização da ferramenta eletrônica Wordsmith Tools 5.0, criada por Mike Scott. Manteve-se, aqui, a decisão de também categorizar os dados até o $2^{\circ}$ nível de delicadeza e de trabalhar, na subrede de 'atitude', apenas com o sistema TIPOS DE ATITUDE.

Silva (2014) trabalhou com roteiros de AD em língua francesa de dois filmes de longa metragem:

- Corpus 1 (C1): Intouchable, de Eric Toledano e Olivier Nakache; e

- Corpus 2 (C2): Minuit à Paris; de Woody Allen.

Os roteiros foram coletados através do contato direto com a audiodescritora francófona por e-mail, facilitando a obtenção dos dois corpora. A análise dos dois roteiros chegou aos seguintes resultados numéricos.

Tabela 3. Ocorrências avaliativas nos roteiros de filme em língua francesa

\begin{tabular}{|c|c|c|c|c|c|c|c|}
\hline & \multicolumn{3}{|c|}{ ATITUDE } & \multicolumn{2}{c|}{ ENGAJ. } & \multicolumn{2}{c|}{ GRAD. } \\
\hline C1 & \multicolumn{3}{|c|}{$46,7 \%$} & \multicolumn{2}{c|}{$9,1 \%$} & \multicolumn{2}{c|}{$44,1 \%$} \\
\hline C2 & \multicolumn{3}{|c|}{$44,1 \%$} & \multicolumn{2}{c|}{$7,6 \%$} & \multicolumn{2}{c|}{$48,2 \%$} \\
\hline & Afeto & Julgamento & Apreciação & Mono & Heter & Força & Foco \\
\hline C1 & $15,3 \%$ & $8,7 \%$ & $22,7 \%$ & $6,9 \%$ & $2,2 \%$ & $39,4 \%$ & $4,7 \%$ \\
\hline C2 & $13 \%$ & $9,3 \%$ & $21,8 \%$ & $5,7 \%$ & $1,9 \%$ & $43,6 \%$ & $4,6 \%$ \\
\hline
\end{tabular}

Fonte: Praxedes Filho e Silva (2014)

A Tabela 3 mostra, nos roteiros em francês, um padrão avaliativo diferente das duas pesquisas descritas anteriormente: não houve predominância de 'gradação' 
sobre as outras duas categorias, mas um equilíbrio entre as avaliações atitudinais $(46,7 \%$ e $44,1 \%)$ e as avaliações graduadoras (44,1\% e 48,2\%). Entretanto, a categoria 'engajamento' continuou a menos expressiva, com percentuais de 9,1\% e $7,6 \%$, talvez devido às limitações de tempo nos intervalos nos quais a AD é inserida.

Quanto ao segundo nível de delicadeza, em 'atitude' houve apenas uma leve predominância de 'apreciação’ (22,7\% e 21,8\%) sobre 'afeto’ (15,3\% e 13\%), mas com uma presença mais significativa de ‘julgamento’ (8,7\% e 9,3\%), comparando com os resultados das ADs de pinturas.

Quanto aos termos mais delicados da subrede de 'engajamento', quase não houve avaliações por 'heteroglossia', cujos percentuais foram 2,2\% e 1,9\% nos dois roteiros, mas foram detectadas avaliações monoglóssicas (6,9\% e 5,7\%) segundo as duas categorias propostas por Praxedes Filho e Magalhães (2015) para os roteiros de pinturas em português.

Finalmente, quanto ao segundo nível de delicadeza da subredede 'gradação', manteve-se uma larga predominância de 'força' (39,4\% e 43,6\%) sobre as avaliações de 'foco' $(4,7 \%$ e 4,6\%), fato explicável, tal como nos roteiros de pintura, pela incidência significativa de avaliações atitudinais, que são passíveis de gradação.

Ao contrário de Silva (2014), Almeida (2015) trabalhou com roteiro de AD de um filme curta-metragem cearense Águas de Romanza (2002), dirigido por Glaucia Soares e Patrícia Baía, adaptação do conto homônimo de Eugênio Leandro. $\mathrm{O}$ roteiro de AD deste curta foi realizado pelos próprios membros do grupo LEAD em 2009. Os resultados obtidos foram os seguintes.

Tabela 4. Ocorrências avaliativas no roteiro de AD do filme Águas de Romanza

\begin{tabular}{|c|c|c|c|c|c|c|}
\hline \multicolumn{3}{|c|}{ ATITUDE } & \multicolumn{2}{c|}{ ENGAJ. } & \multicolumn{2}{c|}{ GRAD. } \\
\hline \multicolumn{3}{|c|}{$36 \%$} & \multicolumn{2}{c|}{$38 \%$} & \multicolumn{2}{c|}{$26 \%$} \\
\hline Afeto & Julgamento & Apreciação & Mono & Heter & Força & Foco \\
\hline $21,3 \%$ & $0 \%$ & $14,7 \%$ & $34,7 \%$ & $4 \%$ & $26 \%$ & $0 \%$ \\
\hline
\end{tabular}

Fonte: Almeida (2015, p. 22)

A Tabela 4 apresenta resultados diferentes dos de Silva (2014) quanto às três grandes áreas de significados avaliativos: houve equilíbrio, porém, entre todas as três categorias de 'atitude’ (36\%), 'engajamento’ (38\%) e 'gradação’ (26\%).

Quanto ao segundo nível de delicadeza de 'atitude', ocorreram apenas avaliações quanto aos sentimentos $(21,3 \%)$ e quanto à estética $(14,7 \%)$, ao passo que não houve avaliação por 'julgamento’, categoria também ausente nos roteiros de $\mathrm{AD}$ de pinturas. Isto talvez se explique, pois, como a versão do roteiro analisada 
data do ano 2009, ela foi elaborada quando os critérios praticados pelo grupo LEAD ainda consideravam o critério de neutralidade.

Quanto ao segundo nível de delicadeza de 'engajamento', houve ocorrência acentuada de 'monoglossia' (34,7\%), dado interessante considerando se tratar de um roteiro para um filme curta-metragem de aproximadamente 14 minutos.

Quanto ao segundo nível de delicadeza de 'gradação', não houve ocorrência de foco e a incidência de avaliações por 'força' teve um percentual menor (26\%), comparada às pesquisas resenhadas acima. É difícil afirmar se isto se deve à extensão menor do curta-metragem ou a outro fator.

Finalmente, Oliveira Junior e Praxedes Filho (2016) realizaram a análise da avaliatividade em dois roteiros de $\mathrm{AD}$ produzidos por alunos de graduação no contexto de uma disciplina do curso de Letras da UECE ministrada pelos dois autores no formato de workshop, pois foram contemplados tanto a parte teórica da $\mathrm{AD}$, quanto a parte prática da elaboração de roteiros. Os roteiros tornaram acessíveis dois curtas-metragens brasileiros:

1) Roteiro 1 (R1): Nosso parabéns ao Freitas ${ }^{10}$, de Felipe Marcondes Sant'Angelo;

2) Roteiro 2 (R2): Café com leite ${ }^{11}$, de Daniel Ribeiro

Num primeiro momento da disciplina, requisitou-se aos alunos que produzissem roteiros de $\mathrm{AD}$ seguindo o parâmetro da neutralidade; depois thes foram apresentados os resultados de Praxedes Filho e Magalhães (2013, 2015), para então refazerem os roteiros sem se preocuparem com a neutralidade. Os dados mostrados a seguir pertencem aos primeiros roteiros, produzidos segundo a neutralidade.

Tabela 5. Ocorrências avaliativas nos roteiros produzidos pelos graduandos da UECE

\begin{tabular}{|c|c|c|c|c|c|c|c|}
\hline & \multicolumn{3}{|c|}{ ATITUDE } & \multicolumn{2}{|c|}{ ENGAJ. } & \multicolumn{2}{|c|}{ GRAD. } \\
\hline $\mathrm{R} 1$ & \multicolumn{3}{|c|}{$73,5 \%$} & \multicolumn{2}{|c|}{13,2} & \multicolumn{2}{|c|}{13,2} \\
\hline $\mathrm{R} 2$ & \multicolumn{3}{|c|}{$73,8 \%$} & \multicolumn{2}{|c|}{11,9} & \multicolumn{2}{|c|}{14,3} \\
\hline & Afeto & Julgamento & Apreciação & Mono & Heter & Força & Foco \\
\hline $\mathrm{R} 1$ & $38,5 \%$ & $25,3 \%$ & $9,6 \%$ & $13,2 \%$ & $0 \%$ & $10,8 \%$ & $2,4 \%$ \\
\hline $\mathrm{R} 2$ & $34,5 \%$ & $21,4 \%$ & $17,8 \%$ & $11,9 \%$ & $0 \%$ & $14,2 \%$ & $0 \%$ \\
\hline
\end{tabular}

Fonte: Oliveira Junior e Praxedes Filho (2016, p. 30)

10. Disponível em: http://portacurtas.org.br/filme/?name=nossos_parabens_ao_freitas.

11.Disponível em: http://portacurtas.org.br/filme/? name=cafe_com_leite. 
Como mostra a Tabela 5, os resultados para as três áreas avaliativas foram bem peculiares neste estudo: houve grande preponderância de 'atitude' (cerca de 73\%) nos dois roteiros, apesar de os alunos terem sido orientados a elaborarem roteiros neutros. Como foi dito na seção 3.1, as avaliações atitudinais de 'afeto' representam linguisticamente os sentimentos de modo subjetivo, justamente o que se deveria evitar num roteiro neutro, mas foi justamente esta a categoria com mais ocorrências, $38,5 \%$ e $34,5 \%$, seguida de 'julgamento' (25,3\% e 21,4\%) e 'apreciação' $(9,6 \%$ e $17,8 \%)$.

A categoria 'engajamento' mais uma vez figurou pouco no computo geral dos três tipos de avaliação (13,2\% e 11,9\%), sendo todas elas monoglóssicas; não ocorreu engajamento heteroglóssico.

Finalmente, é inusitado que tenha havido tão baixa ocorrência de 'gradação' $(13,2 \%$ e $14,3 \%)$, apesar de haver nestes roteiros uma grande quantidade de avaliações atitudinais, que são graduáveis. Preservou-se, porém, a preponderância de 'força' ( $10,8 \%$ e $14,2 \%)$ sobre 'foco' $(2,4 \%$ e $0 \%)$.

Apesar de até aqui ter sido descrito um número diminuto de pesquisas, podese constatar a impossibilidade de neutralidade nos roteiros de $A D$, confirmando empiricamente aquilo já sabido de antemão no nível da teoria (MARTIN; WHITE, 2005; JAKOBSON, 2000 [1959]). Todavia, tratou-se de um passo necessário, pelo fato de o parâmetro da neutralidade ter-se cristalizado numa espécie de "cláusula pétrea" da AD no meio não acadêmico.

Uma vez constatada a impossibilidade de os roteiros de AD serem neutros, os pesquisadores do grupo LEAD deram um passo adiante nas pesquisas com roteiros de $\mathrm{AD}$, no sentido de analisar e descrever o perfil das escolhas avaliativas características desta modalidade de TAVa. Esta nova etapa da pesquisa é descrita na seção a seguir.

\subsection{Estilo interpretativo}

Dentro dos procedimentos teórico-metodológicos disponibilizados pela LSF e pelo Sistema de Avaliatividade, tanto é possível traçar os padrões avaliativos de um determinado indivíduo (como, por exemplo, um autor de literatura ou um político), quanto é possível traçar os padrões avaliativos que certos contextos de uso impõem aos usuários da língua. No primeiro caso, trata-se de uma pesquisa de assinatura avaliativa (MARTIN; WHITE, 2005, p. 203), enquanto que, no segundo caso, tratase de uma pesquisa de estilo avaliativo (p. 161). Praxedes Filho e Magalhães (2013; 2015) referem-se a estes dois tipos de pesquisa pela terminologia superordenada estilo interpretativo. 
Nesta nova etapa das pesquisas do grupo LEAD, já foram realizadas quatro pesquisas: Oliveira Junior (2016), Farias Junior (2016), Lima (2016) e Santos, Farias Junior e Praxedes Filho (no prelo). Um diferencial destas pesquisas foi a categorização dos dados via rede de sistemas de avaliatividade até o último nível de delicadeza de 'atitude', 'engajamento' e 'gradação'. Porém, aqui, dadas as limitações de espaço, os dados destas pesquisas serão apresentados apenas até o segundo nível de delicadeza. Além disto, no que tange à interpretação dos dados, será dada ênfase à subrede de 'atitude', cotejando os dados do sistema TIPOS DE ATITUDE aos dos sistemas de POLARIDADE e TIPO DE REALIZAÇÃO, por entendermos que esta abordagem permite discernir melhor a relação das avaliações do audiodescritor com os efeitos estéticos do objeto descrito.

Oliveira Junior (2016) examinou a assinatura avaliativa de roteiros de AD de filmes curta-metragem com temática LGBTTI $^{12}$ produzidos por um mesmo audiodescritor cis-homem ${ }^{13}$ e homossexual ${ }^{14}$, membro do grupo LEAD. O corpus foi composto pelos roteiros de $\mathrm{AD}$ de seis curtas-metragens nacionais, três do gênero ficção (F) e três do gênero documentário (D). Os três curtas-metragens de ficção são:

- F1: Café com leite, de Daniel Ribeiro;

- F2: O Móbile, de Lilian Werneck;

- F3: Eu não quero voltar sozinbo, de Daniel Ribeiro;

Os roteiros de $\mathrm{AD}$ de ficção apresentam um padrão interessante em comparação aos estudos anteriores, nos quais as avaliações por 'atitude' e 'gradação' tendem a se equipararem (com exceção de Oliveira Junior e Praxedes Filho (2016)); porém, nesta investigação, houve uma predominância enorme de avaliações por 'atitude' e uma ocorrência muito baixa de 'gradação', como mostra a Tabela 6.

12. Lésbicas, Gays, Bissexuais, Transgêneros, Travestis e Intersexuais.

13. Um tipo de identidade de gênero. É cisgênero toda pessoa que sente um alinhamento entre seu sexo biológico e sua autoimagem, sua percepção subjetiva de si mesmo. Cis-homem, portanto, é a pessoa que nasce com órgão genital masculino e se enxerga como pertencente ao gênero masculino.

14. Um tipo de orientação sexual: pessoa que sente atração por pessoas do mesmo sexo. 
Tabela 6. Ocorrências avaliativas nos roteiros de AD dos curtas de ficção

\begin{tabular}{|c|c|c|c|c|c|c|}
\hline \multicolumn{3}{|c|}{ Atitude } & \multicolumn{2}{|c|}{ Engajamento } & \multicolumn{2}{|c|}{ Gradação } \\
\hline \multicolumn{3}{|c|}{$83,7 \%$} & \multicolumn{2}{|c|}{$6,9 \%$} & \multicolumn{2}{|c|}{$9,4 \%$} \\
\hline Afeto & $\begin{array}{l}\text { Julga- } \\
\text { mento }\end{array}$ & $\begin{array}{c}\text { Aprecia- } \\
\text { ção }\end{array}$ & Mono & Heter & Força & Foco \\
\hline $35,8 \%$ & $41,9 \%$ & $6,0 \%$ & $6,8 \%$ & $0,1 \%$ & $4,8 \%$ & $4,6 \%$ \\
\hline \multirow{3}{*}{ 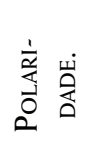 } & Pos & $18,4 \%$ & $18,6 \%$ & $1,6 \%$ & & \\
\hline & Amb & $8,7 \%$ & $17,7 \%$ & $3,8 \%$ & & \\
\hline & Neg & $8,7 \%$ & $5,6 \%$ & $0,6 \%$ & & \\
\hline \multirow{2}{*}{ 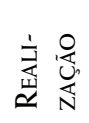 } & Ins & $26,1 \%$ & $38,4 \%$ & $4,7 \%$ & & \\
\hline & Evo & $9,7 \%$ & $3,5 \%$ & $1,3 \%$ & & \\
\hline
\end{tabular}

Fonte: Oliveira Junior (2016)

Para os roteiros de $\mathrm{AD}$ do gênero ficção, as avaliações por 'atitude' totalizaram $83,7 \%$, consistindo majoritariamente de sentimentos afetivos $(35,8 \%)$ e éticos $(41,9 \%)$. Resultado inovador em relação aos roteiros de AD de obras de arte analisados por Praxedes Filho e Magalhães $(2013 ;$ 2015), cujos posicionamentos atitudinais eram majoritariamente estéticos, haja vista tratarem-se de ADs de obras de arte, ao invés de filmes.

Mas é intrigante que haja um baixíssimo índice de avaliações por 'apreciação', se compararmos os resultados de Oliveira Junior (2016) com as pesquisas anteriores que se debruçaram sobre ADs de filmes: (i) nos dois roteiros de $\mathrm{AD}$ em francês (SILVA, 2014), os filmes audiodescritos também eram obras de ficção e as avaliações estéticas giravam em torno de $22 \%$ (vide Tabela 3 ), havendo certo equilíbrio entre os três tipos de avaliações atitudinais; (ii) no estudo de caso da AD de Águas de Romanza (ALMEIDA, 2015), não houve quaisquer avaliações éticas, mas apenas por 'afeto' e 'apreciação' (vide Tabela 4); (iii) nos dois roteiros produzidos pelos alunos de graduação em Letras da UECE (OLIVEIRA JUNIOR; PRAXEDES FILHO, 2016), houve alguma predominância de avaliações por 'afeto' e 'julgamento', mas sem que isso ofuscasse as avaliações estéticas.

A presença tímida de 'apreciação' (6\%) nos roteiros de AD de ficção talvez possa estar ligada à relação subjetiva do audiodescritor com a temática LGBTTI dos curtas-metragens. Visto que o audiodescritor é cis-homem de orientação homossexual, vivendo num país extremamente homofóbico e transfóbico como é o Brasil, a temática dos curtas em protagonizar a vida de homossexuais e pessoas trans 
pode, por hipótese, tê-lo incitado a priorizar em suas ADs a exaltação das emoções e comportamentos dos personagens dos curtas em detrimento de aspectos estéticos das obras.

Esta possibilidade parece ser corroborada pelos dados referentes aos sistemas de POLARIDADE e TIPOS DE REALIZAÇão. Para os três tipos de posicionamentos atitudinais, as avaliações tiveram polaridade majoritariamente 'positiva' e 'ambígua' (vide Tabela 6), e foram instaladas no texto principalmente de forma 'inscrita', explícita (vide Tabela 6). Quanto à subrede de 'engajamento', o resultado seguiu a tendência das pesquisas anteriores sobre filmes, havendo poucas avaliações por posicionamento da voz textual e, quando ocorreram, se deram apenas por 'monoglossia'. Finalmente, com relação à subrede de 'gradação', é inusitado que haja uma quantidade de significados atitudinais, que são graduáveis, mas uma quantidade irrisória de gradações, apenas 9,4\%, com distribuição equilibrada entre 'força' e foco'.

Passando agora aos filmes curta-metragem do gênero documentário, eles são três:

- D1: A Matriarca, de Marina Mesquita;

- D2: Donaléo, de Rodrigo Paulino,

- D3: Quem tem medo de Cris Negão?,de René Guerra

Os roteiros de $\mathrm{AD}$ deste segundo gênero fílmico, ao contrário do que aconteceu com os roteiros de ficção, apresentaram um resultado mais próximo ao das pesquisas anteriores: apesar da predominância das avaliações atitudinais, também houve uma quantidade significativa de gradações, como mostra a Tabela 7 .

Tabela 7. Ocorrências avaliativas nos roteiros de AD dos curtas documentários

\begin{tabular}{|c|c|c|c|c|c|c|}
\hline \multicolumn{3}{|c|}{ Atitude } & \multicolumn{2}{c|}{ Engajamento } & \multicolumn{2}{c|}{ Gradação } \\
\hline \multirow{2}{*}{ Afeto } & $\begin{array}{c}\text { Julga- } \\
\text { mento }\end{array}$ & $\begin{array}{c}\text { Aprecia- } \\
\text { ção }\end{array}$ & Mono & Heter & \multirow{2}{*}{ Força } & Foco \\
\hline $20,3 \%$ & $34,5 \%$ & $12,5 \%$ & $5,4 \%$ & $0 \%$ & $24,4 \%$ & $2,9 \%$ \\
\hline \multirow{2}{*}{ Pos } & $6,0 \%$ & $5,4 \%$ & $0,6 \%$ & & \\
\cline { 1 - 5 } & Amb & $11,4 \%$ & $26,7 \%$ & $7,7 \%$ & \\
\cline { 2 - 6 } & Neg & $2,9 \%$ & $2,4 \%$ & $4,2 \%$ & & \\
\hline
\end{tabular}




\begin{tabular}{|c|c|c|c|c|}
\hline \multirow{2}{*}{ 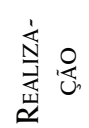 } & Ins & $12,5 \%$ & $32,8 \%$ & $11,9 \%$ \\
\hline & Evo & $7,8 \%$ & $1,7 \%$ & $0,6 \%$ \\
\hline
\end{tabular}

Fonte: Oliveira Junior (2016)

A maioria das avaliações foi de 'atitude' (67,3\%), principalmente por 'julgamento’ $(34,5 \%)$ e afeto $(20,3 \%)$; porém, também houve uma quantidade significativa de 'apreciação' (12,5\%). Quanto aos sistemas de POLARIDADE e TIPO DE REALIZAÇÃO, nos três tipos de avaliações atitudinais, a maioria das ocorrências foi ambígua e inscrita. A predominância de ambiguidade sobre as polaridades positiva e negativa aponta para a parcimônia do audiodescritor - cis-homem e homossexual -, em demonstrar sua subjetividade: em nenhum momento ele avaliou negativamente a comunidade LGBTTI, mas também não teve a mesma abertura em realizar um número maior de avaliações positivas à temática, como foi o caso no gênero ficção (vide Tabela 6).

Segundo Oliveira Junior (2016, p. 114), uma possibilidade para estes resultados diferirem dos obtidos nos roteiros para ficção pode ser devido ao caráter aberto do documentário, no sentido de que o roteiro deste gênero fílmico não está finalizado já na pré-produção do filme, antes do início das filmagens, como é o caso dos filmes de ficção. Pelo contrário, o diretor do documentário não controla que tipos de respostas os participantes darão às suas perguntas (no caso de haver entrevistas), nem controla suas condutas e comportamentos. Logo, o produto final tenta produzir na plateia um efeito de verossimilhança com a realidade, uma sensação de fidedignidade documental. Talvez o audiodescritor tenha tentado reproduzir este efeito do gênero documentário nos roteiros de AD. As ocorrências de avaliações por 'engajamento' foram poucas $(5,4 \%)$ e exclusivamente por 'monoglossia'. Finalmente, as avaliações por 'gradação' ficaram numa posição intermediária $(27,3 \%)$, consistindo principalmente de ocorrências de 'força'.

A segunda pesquisa de estilo interpretativo conduzida pelo grupo LEAD foi a de Farias Junior (2016), que trabalhou com o roteiro de AD em português do filme Ensaio sobre a cegueira, uma adaptação hollywoodiana do romance homônimo do escritor português José Saramago. Tratou-se de um estudo de caso descritivoexploratório. Justifica-se a escolha da AD deste filme por ter causado grande comoção entre as PcDVs dos Estados Unidos da América, que entenderam que o filme denegria este grupo social, levando inclusive algumas pessoas a boicotarem o filme. No Brasil, entretanto, as PcDVs entenderam que a cegueira abordada no 
filme é metafórica, uma alusão à "cegueira da alma", às emoções destrutivas do ser humano.

$\mathrm{O}$ roteiro de $\mathrm{AD}$ foi elaborado pelo grupo mineiro Associação Mídia e Acessibilidade (MIDIACE) ${ }^{15}$, revisado pelo grupo baiano Tradução, Mídia e Audiodescrição (TRAMAD) $)^{16}$ e disponibilizado em DVD comercial lançado no Brasil.

Os resultados da pesquisa mostram, quanto às três grandes áreas de avaliação, a mesma tendência, na qual as avaliações atitudinais figuram em primeiro lugar, seguidas das avaliações de 'gradação' em segundo lugar e, por último, as avaliações por 'engajamento', como ilustra a Tabela 8.

Tabela 8. Ocorrências avaliativas nos roteiros de AD do filme Ensaio sobre a cegueira

\begin{tabular}{|c|c|c|c|c|c|c|}
\hline \multicolumn{3}{|c|}{ Atitude } & \multicolumn{2}{|c|}{ Engajamento } & \multicolumn{2}{|c|}{ Gradação } \\
\hline \multicolumn{3}{|c|}{57,7} & \multicolumn{2}{|c|}{7,3} & \multicolumn{2}{|c|}{34,9} \\
\hline Afeto & $\begin{array}{l}\text { Julga- } \\
\text { mento }\end{array}$ & $\begin{array}{l}\text { Aprecia- } \\
\text { ção }\end{array}$ & Mono & Heter & Força & Foco \\
\hline $23,2 \%$ & $21 \%$ & $13,5 \%$ & $3,8 \%$ & $3,5 \%$ & $34,9 \%$ & $0 \%$ \\
\hline \multirow{3}{*}{ ص } & Pos & $12 \%$ & $10,5 \%$ & $2,6 \%$ & & \\
\hline & $\mathrm{Amb}$ & $0,7 \%$ & $1,5 \%$ & $7,7 \%$ & & \\
\hline & Neg & $10,5 \%$ & $9 \%$ & $3,1 \%$ & & \\
\hline \multirow{2}{*}{ 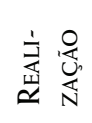 } & Ins & $3,7 \%$ & $6,4 \%$ & $11,2 \%$ & & \\
\hline & Evo & $19,5 \%$ & $14,6 \%$ & $2,3 \%$ & & \\
\hline
\end{tabular}

Fonte: Farias Junior (2016)

É possível perceber um maior equilíbrio entre as ocorrências de 'atitude' $(57,7 \%)$ e 'gradação' (34,9\%), tal como nas pesquisas de Silva (2014) (vide Tabela 3) e Almeida (2015) (vide Tabela 4), consequentemente, se distanciando dos resultados encontrados por Oliveira Junior (2016) e Oliveira Junior e Praxedes Filho (2016).

Isto talvez se deva às exigências do mercado audiovisual, em que a empresa contratante dos serviços de audiodescrição exige que o audiodescritor siga um determinado protocolo, no sentido de minimizar a possibilidade de o grande público se ofender com a obra audiovisual e, porventura, queira processar a empresa contratante. No âmbito da legendagem (tanto para ouvintes, quanto para surdos), 
esta prática de interdição editorial é lugar comum; logo, não causaria espanto encontrá-la na AD.

Os roteiros estudados por Silva (2014) e Farias Junior (2016) foram produzidos em contexto comercial. O roteiro estudado por Almeida (2015) foi elaborado num contexto não comercial, mas por um audiodescritor experimentado com o mercado. Já os roteiros analisados por Oliveira Junior (2016) e Oliveira Junior e Praxedes Filho (2016) foram construídos em contextos não comerciais; logo, sem a necessidade de seguir um protocolo editorial. Isto talvez explique a peculiaridade dos roteiros de ficção analisados por Oliveira Junior (2016).

Estas hipóteses parecem corroboradas pelos padrões de TIPO DE REALIZAÇÃO das avaliações atitudinais encontradas por Farias Junior (2016): para os sentimentos emocionais e éticos, a maioria das ocorrências foi evocada (implícita), ao contrário de 'apreciação', majoritariamente inscrita. Desse modo, é defensável pensar que esta possa ser uma estratégia para diminuir o impacto da POLARIDADE das avaliações por 'atitude': haja vista que quase não houve avaliações ambíguas de 'afeto' e ‘julgamento’, que são justamente as avaliações sobre os comportamentos e respostas emocionais dos personagens, sendo estes são avaliados positiva ou negativamente de modo suavizado.

Quanto às avaliações por engajamento, mais uma vez foram as menos numerosas $(7,3 \%)$, mas com uma quantidade um pouco maior de posicionamentos heteroglóssicos $(3,5 \%)$. As avaliações por 'gradação' foram todas do tipo 'força'.

A terceira pesquisa sobre estilo interpretativo foi a de Lima (2016), que observou a assinatura avaliativa de roteiros de AD, elaborados por uma mesma audiodescritora, para três monumentos históricos da cidade de Fortaleza-CE - A Coluna da Hora, A Escadaria da Praça General Tibúrcio (Praça dos Leões) e A Estátua da Iracema Guardiã -, escolhidos por sua importância cultural e histórica para a capital cearense, bem como pelas dimensões destacadas na paisagem urbana e pela riqueza de detalhes.

A audiodescritora dos roteiros foi uma tradutora audiovisual em formação do curso de Letras da UECE e bolsista de iniciação científica do grupo LEAD. Para a confecção dos roteiros, a audiodescritora visitou os monumentos históricos, registrou-os em fotos, realizou coleta de informações sobre a criação e o contexto de localização dos monumentos, e finalmente elaborou os roteiros de AD. Terminados os roteiros, Lima (2016) analisou-os e obteve os seguintes resultados, conforme exposto na Tabela 9. 
Tabela 9. Ocorrências avaliativas nos roteiros de AD de monumentos históricos

\begin{tabular}{|c|c|c|c|c|c|c|}
\hline \multicolumn{3}{|c|}{ Atitude } & \multicolumn{2}{|c|}{ Engajamento } & \multicolumn{2}{|c|}{ Gradação } \\
\hline \multicolumn{3}{|c|}{$40,7 \%$} & \multicolumn{2}{|c|}{$6,7 \%$} & \multicolumn{2}{|c|}{$52,5 \%$} \\
\hline Afeto & $\begin{array}{l}\text { Julga- } \\
\text { mento }\end{array}$ & $\begin{array}{l}\text { Aprecia- } \\
\text { ção }\end{array}$ & Mono & Heter & Força & Foco \\
\hline $3,4 \%$ & $6,8 \%$ & $30,5 \%$ & $1,7 \%$ & $5 \%$ & $37,2 \%$ & $15,3 \%$ \\
\hline \multirow{3}{*}{ 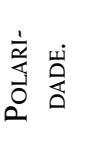 } & Pos & $1,7 \%$ & $3,4 \%$ & $6,7 \%$ & & \\
\hline & Amb & $0 \%$ & $0 \%$ & $22,1 \%$ & & \\
\hline & Neg & $1,7 \%$ & $3,4 \%$ & $1,7 \%$ & & \\
\hline \multirow{2}{*}{ 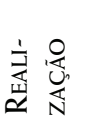 } & Ins & $0 \%$ & $3,4 \%$ & $30,5 \%$ & & \\
\hline & Evo & $3,4 \%$ & $3,4 \%$ & $0 \%$ & & \\
\hline
\end{tabular}

Fonte: Lima (2016)

Lima (2016) obteve resultados semelhantes aos de Praxedes Filho e Magalhães $(2013$; 2015), o que é compreensível, pois aquela pesquisa, assim como estas, lida com objetos que almejam produzir enlevo estético no observador: houve certo equilíbrio entre as avaliações atitudinais $(40,7 \%)$ e de 'gradação', com predominância desta última $(52,5 \%)$.

Quanto ao segundo nível de delicadeza dos significados atitudinais, foram as avaliações estéticas as mais numerosas $(30,5 \%)$, mais uma vez repetindo os padrões encontrados em Praxedes Filho e Magalhães (2013; 2015), apontando, talvez, na direção do estilo interpretativo de roteiros de $\mathrm{AD}$ para objetos estáticos (monumentos, pinturas, esculturas etc.). É curioso, porém, que a audiodescritora, quanto aos significados estéticos, tenha enfatizado avaliações ambíguas $(22,1 \%)$, apesar de ser participante do grupo LEAD e estar imersa nas pesquisas do grupo sobre a desmistificação do parâmetro da neutralidade em roteiros de AD. Finalmente, em relação às formas de realização das avaliações atitudinais, a audiodescritora, no que tange a categoria 'apreciação', deu preferência a fazê-lo explicitamente $(30,5 \%)$, estratégia inversa à utilizada nas poucas avaliações por 'afeto', que foram apenas do tipo 'evocada'.

Houve poucos posicionamentos por 'engajamento', apenas 6,7\% do total de avaliações, porém com o diferencial de que os posicionamentos heteroglóssicos (5\%) foram mais numerosos que os posicionamentos monoglóssicos $(1,7 \%)$. Talvez uma consequência do contato com o grupo LEAD, visto que, nos corpora analisados nas pesquisas anteriores, a tendência é que haja predominância de 'monoglossia'. 
Finalmente, com relação às avaliações por 'gradação', a maior parte foi do tipo 'força' $(32,7 \%)$.

Completando o quadro de pesquisas realizadas sobre estilo interpretativo no grupo LEAD, há a pesquisa de Santos, Farias Junior e Praxedes Filho (no prelo), que é a primeira pesquisa baseada no Sistema de Avaliatividade a trabalhar com roteiros de $\mathrm{AD}$ de peça de teatro; portanto, tratou-se de um estudo de caso descritivo-exploratório. $\mathrm{O}$ corpus consistiu do roteiro de $\mathrm{AD}$ da peça infantil A Vaca Lelé, elaborado em equipe por um casal de audiodescritores profissionais e cuja colaboração frequente se dá tanto na feitura, quanto na revisão de roteiros de

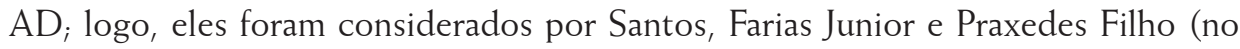
prelo) como se fossem um único audiodescritor. A Tabela 10 lista os resultados encontrados.

Tabela 10. Ocorrências avaliativas nos roteiros de AD de peça teatral infantil

\begin{tabular}{|c|c|c|c|c|c|c|}
\hline \multicolumn{3}{|c|}{ Atitude } & \multicolumn{2}{|c|}{ Engajamento } & \multicolumn{2}{|c|}{ Gradação } \\
\hline \multicolumn{3}{|c|}{$73,4 \%$} & \multicolumn{2}{|c|}{$0 \%$} & \multicolumn{2}{|c|}{$26,6 \%$} \\
\hline Afeto & $\begin{array}{l}\text { Julga- } \\
\text { mento }\end{array}$ & $\begin{array}{l}\text { Aprecia- } \\
\text { ção }\end{array}$ & Mono & Heter & Força & Foco \\
\hline $21,7 \%$ & $10,9 \%$ & $40,8 \%$ & $0 \%$ & $0 \%$ & $26,6 \%$ & $0 \%$ \\
\hline \multirow{3}{*}{ 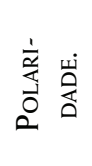 } & Pos & $10,2 \%$ & $0,7 \%$ & $0 \%$ & & \\
\hline & Amb & $0 \%$ & $0 \%$ & $34,7 \%$ & & \\
\hline & Neg & $11,5 \%$ & $15 \%$ & $6,1 \%$ & & \\
\hline \multirow{2}{*}{ 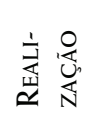 } & Ins & $2 \%$ & $0 \%$ & $35,3 \%$ & & \\
\hline & Evo & $19,7 \%$ & $10,9 \%$ & $5,5 \%$ & & \\
\hline
\end{tabular}

Fonte: Santos, Farias Junior e Praxedes Filho (no prelo)

Quanto às três grandes áreas de significados avaliativos, o padrão encontrado neste estudo de caso se assemelha, à primeira vista, ao encontrado por Oliveira Junior (2016) para os curtas-metragens de ficção e documentários, nos quais a frequência de significados atitudinais foi bem mais que a metade de todas as avaliações; no roteiro de AD da peça infantil, o termo 'atitude' ocorreu em $73,4 \%$ das avaliações. Porém, estas semelhanças mantiveram-se no primeiro nível de delicadeza, pois, no nível seguinte, dos três tipos de avaliações atitudinais, os significados estéticos foram os mais recorrentes $(40,8 \%)$, justamente o contrário do que aconteceu nos 
dois gêneros observados por Oliveira Junior (2016), em que a predominância foi de avaliações de 'afeto' e 'julgamento'.

Haja vista que a exibição de filmes e a encenação de peças de teatro têm em comum o fato de serem expressas via imagens em movimento, bem como de se desenvolverem no tempo pelo desenrolar de uma trama ou enredo, não seria exagero supor que os padrões avaliativos dos roteiros de $\mathrm{AD}$ destas duas categorias tendessem a convergir. Mas os resultados preliminares deste estudo de caso parecem refutar tal hipótese: a grande quantidade de avaliações por 'apreciação' na AD da peça infantil A Vaca Lelé se assemelha mais aos padrões avaliativos encontrados nas ADs de objetos estáticos, como obras de arte (PRAXEDES FILHO; MAGALHÃES, 2013; 2015) e monumentos históricos (LIMA, 2016). Como se trata de um estudo de caso, não é possível fazer maiores generalizações, mas isto talvez se deva às diferenças entre um palco de teatro e uma tela de cinema: num filme, a câmera pode se aproximar dos personagens para enfatizar a dramaticidade de sua atuação e detalhes de suas ações, propiciando maior quantidade de avaliações de 'afeto' e 'julgamento' no roteiro de $\mathrm{AD}_{i}$ já no caso de uma peça de teatro, cada pessoa da plateia (incluindo o audiodescritor) permanece sentada no mesmo assento, dependendo apenas da visão a olho nu para identificar o que acontece no palco, situação que talvez desfavoreça a descrição da dramaticidade da atuação e, consequentemente, induzindo o audiodescritor a dar mais atenção a aspectos do cenário ou do figurino, elementos estes avaliados via 'apreciação'.

Sobre as outras duas áreas de significados avaliativos, há o seguinte: por um lado, não ocorreram quaisquer posicionamentos por 'engajamento', nem heteroglóssicos - fato talvez explicável devido ao público-alvo ser composto de crianças, possivelmente ainda imaturas para serem suscetíveis à modalização -, nem monoglóssicos - talvez devido à parceria dos dois audiodescritores na revisão do roteiro; por outro lado, houve $26,6 \%$ de avaliações por 'gradação', todas elas do tipo 'força'. Isto encerra nossa discussão sobre o percurso investigativo realizado pelos membros do grupo LEAD, via Sistema de Avaliatividade, sobre o problema da neutralidade e sobre o estilo interpretativo em AD.

\section{CONSIDERAÇÕES FINAIS}

O objetivo deste artigo foi apresentar a trajetória de pesquisas do grupo LEAD (UECE) sobre o critério da neutralidade em $\mathrm{AD}$, modalidade de tradução audiovisual acessível dirigida a PcDVs. O arcabouço teórico-metodológico orientador das investigações foi a Semiótica Social hallidayana (HALLIDAY, 1978), 
mais especificamente através da Linguística Sistêmico-Funcional (HALLIDAY; MATTHIESSEN, 2014) e, dentro desta, o Sistema de Avaliatividade (MARTIN, WHITE, 2005).

Na primeira seção deste texto, discutimos brevemente a definição de AD (DE COSTER; MÜLHEIS, 2007) no contexto da expansão de suas aplicações nos mais diversos espaços, abordando brevemente o critério da neutralidade, parâmetro defendido pela literatura não acadêmica da área (SNYDER, 2008).

$\mathrm{Na}$ segunda seção, delimitamos a $\mathrm{AD}$ dentro da área disciplinar dos Estudos da Tradução Audiovisual (INGHILERI, 2009), caracterizando-a como uma modalidade de tradução audiovisual acessível (TAVa) (JIMENEZ, 2010; ADERALDO, 2014) e alocando-a junto às modalidades da Legendagem para surdos e ensurdecidos (LSE) e da Janela de língua de sinais. Discutimos ainda o conceito de acessibilidade universal (ALONSO, 2007), alertando para seu caráter abrangente, não limitado à mera adequação de espaços físicos a pessoas cadeirantes. Tomando esta universalidade como ponto de partida, discutimos a pertinência do critério da neutralidade em $\mathrm{AD}$, apontando teoricamente sua inviabilidade (JAKOBSON, 2000 [1959]), tese reforçada pelo relato de Holland (2009) na sua atuação na AD de teatro.

Foi o impasse entre defensores e críticos do critério da neutralidade que motivou os membros do grupo LEAD a conduzirem análises empíricas de roteiros de AD para verificar a pertinência deste critério. Tomou-se como base o Sistema de Avaliatividade, apresentado na terceira seção, na qual foram descritas as subredes de sistemas das três grandes áreas de significados avaliativos ('atitude', 'engajamento' e 'gradação') até o segundo nível de delicadeza.

Logo em seguida, na quarta seção, foram arroladas as pesquisas completadas até a escrita deste artigo, iniciando com a descrição das duas primeiras pesquisas realizadas por Praxedes Filho e Magalhães $(2013$; 2015), que trataram da neutralidade de roteiros de $\mathrm{AD}$ de pinturas, tanto em língua inglesa, quanto no português brasileiro, ambas constatando a não neutralidade dos roteiros. Em seguida, tratou-se das três pesquisas sobre a neutralidade em roteiros de $\mathrm{AD}$ de filmes - Silva (2014), Almeida (2015) e Oliveira Junior e Praxedes Filho (2016) -, todas elas mais uma vez constatando a não neutralidade dos roteiros analisados. Por fim, descreveu-se as quatro pesquisas versando sobre estilo interpretativo, ou seja, não mais preocupadas em aferir a presença ou ausência de neutralidade nos roteiros de $\mathrm{AD}$, mas de encontrar nestes padrões avaliativos que possam caracterizar ora um subgênero de roteiro (estilo avaliativo), ora as características de um(a) dado(a) audiodescritor(a). 
Ao longo de todo este percurso investigativo, foi ficando cada vez mais claro aos membros do grupo LEAD a natureza eminentemente multimodal do roteiro de $\mathrm{AD}$, bem como sua flagrante integração semiótica com o objeto audiodescrito, demandando, assim, pesquisas com novos desenhos metodológicos que viabilizem análises nas quais as dimensões verbal e não verbal sejam melhor integradas, permitindo maior grau de replicabilidade das pesquisas futuras sobre padrões avaliativos em roteiros de AD.

\section{REFERÊNCIAS BIBLIOGRÁFICAS}

ADERALDO, M. F. (2014). Proposta de parâmetros descritivos para audiodescrição de pinturas artísticas: interface da tradução audiovisual acessível e a semiótica social-multimodalidade. 201f. Tese (Doutorado) - Pós-graduação em Estudos Linguísticos, Universidade Federal de Minas Gerais, Belo Horizonte.

ALMEIDA, J. M. B. (2015). O roteiro de audiodescrição do filme de curta-metragem 'Águas de Romanza' é neutro? uma pergunta para o sistema de avaliatividade. 39f. Trabalho de Conclusão de Curso (Bacharelado) - Centro de Humanidades, Universidade Estadual do Ceará, Fortaleza.

ALONSO, F. (2007). Algo más que suprimir barreras: conceptos y argumentos para una accesibilidad universal. TRANS. Revista de Traductología, Málaga, n. 11, pp. 15-30.

BEDNAREK, M. Emotion talk across corpora. Houndmills e New York: Palgrave Macmillan, 2008.

BRASIL. (1922). Decreto n. 4.559 de 21 de agosto de 1922. Adquire propriedade plena e definitiva da letra do hino nacional. Disponível em: < http://www2.camara. leg.br/legin/fed/decret/1920-1929/decreto-4559-21-agosto-1922-568211 publicacaooriginal-91607-pl.html>. Acesso 09 mai 2017.

CÂMARA dos deputados. (2006). Íntegra do discurso presidente da Assembléia Nacional Constituinte, Dr. Ulysses Guimarães. Disponível em: < http://www2. camara.leg.br/camaranoticias/radio/materias/CAMARA-E-HISTORIA/339277INTEGRA-DO-DISCURSO-PRESIDENTE-DA-ASSEMBLEIA-NACIONALCONSTITUINTE,--DR.-ULYSSES-GUIMARAES-(10-23).html>. Acesso em: 09 mai 2017.

DE COSTER, K.; MÜHLEIS, V. (2007). Intersensorial translation: visual art made up by words. In: DIAZ-CINTAS, J.; ORERO, P.; REMAEL, A. (Orgs.). Media for all: 
subtitling for the deaf, audio description, and sign language. Amsterdam; New York: Rodopi, pp. 189-201.

DOSTOIÉVSKI, F. (1866). Crime e castigo. Tradução de Paulo Bezerra. 6. ed. São Paulo: Editora 34, 2009.

FARIAS JUNIOR. L. (2016). Roteiro de AD em português do filme 'Ensaio sobre a cegueira': um estudo descritivo sobre o estilo avaliativo do texto. 255f. 2016. Dissertação (Mestrado) Pós-graduação em Linguística Aplicada, Universidade Estadual do Ceará, Fortaleza.

HALLIDAY, M. A. K. (1978). Language as social semiotic: the social interpretation of language and meaning. London: Edward Arnold.

HALLIDAY, M. A. K.; MATTHIESSEN, C. (2014). Halliday's Introduction to functional grammar. 4 ed. Londres e Nova York: Routledge.

HOLLAND, A. (2009). Audio description in the theater and the visual arts: images into words. In: DIAZ-CINTAS, J.; ANDERMAN, G. (Orgs.). Audiovisual translation: language transfer on screen. Hampshire e Nova Iorque: Palgrave Macmillan, pp. 170-185.

INGHILLERI, M. (2009). Audiovisual translation. In: BAKER, M.; SALDANHA, G. (Orgs.). Routledge encyclopedia of Translation Studies. London e New York: Routledge, pp. $13-20$.

JAKOBSON, R. (1959). On linguistic aspects of Translation. In: VENUTI, L. (Org.). The translation studies reader. Londres e Nova York: Routledge, 2000, pp. 113-118

JIMÉNEZ, C. (2010). Un corpus de cine. Fundamentos teóricos de la audiodescripción. In: JIMÉNEZ, C.; RODRÍGUEZ, A.; SEIBEL, C. (Orgs.). Un corpus de cine: teoría y práctica de la audiodescripción. Granada: Ediciones Tragacanto, pp. 13-56.

LIMA, A. K. F. (2016). A audiodescrição de monumentos de Fortaleza: um estudo sobre o estilo interpretativo da perspectiva da assinatura avaliativa da audiodescritora. $52 \mathrm{f}$. 2016. Trabalho de Conclusão de Curso (Bacharelado) - Centro de Humanidades, Universidade Estadual do Ceará, Fortaleza.

MAGALHÃES, C. M.; ARAÚJO, V. L. S. (2012). Metodologia para elaboração de audiodescrições para museus baseada na semiótica social e multimodalidade: introdução teórica e prática. Revista Latinoamericana de Estudios del Discurso. v. 12, pp. $31-56$ 
MARTIN, J. R.; ROSE, D. (2007). Working with discourse: meaning beyond the clause. London/New York: Continuum.

MARTIN, J. R.; WHITE, P. R. R. (2005). The language of evaluation: appraisal in English. Hampshire: Palgravre Macmillan.

OLIVEIRA JUNIOR, J. (2016). Desmistificando a neutralidade em AD via sistema de avaliatividade: um estudo exploratório-descritivo sobre a assinatura do audiodescritor de curtas de temática LGBTT. 205f. Tese (Doutorado) - Pós-graduação em Linguística Aplicada, Universidade Estadual do Ceará, Fortaleza.

OLIVEIRA JUNIOR, J.; PRAXEDES FILHO, P. H. L. (2016). A (não)neutralidade em roteiros de audiodescrição-AD de filmes de curta-metragem via sistema de avaliatividade. In: CARPES, D. S. (Org.). Audiodescrição: práticas e reflexões. Santa Cruz do Sul-RS: Catarse, pp. 22-36.

PARLATUBEBRASIL. (2015). Dep. Jair Bolsonaro (PP-RJ) apresenta livro didático do kit gay. Disponível em: <https://www.youtube.com/watch?v=kwHmrkzR6GA> . Acesso em: 09 mai 2017.

PERUCCI, G. (2016). Genuinamente brasileira e familiar, a pinga é parte da nossa cultura. Correio Braziliense. 06 fev. 2016. Disponível em: <http://www.correiobraziliense. com.br/app/noticia/turismo/2016/02/06/interna_turismo,516815/genuinamentebrasileira-e-familiar-a-pinga-e-parte-da-nossa-cultura.shtml $>$. Acesso em 09 mai 2017.

PRAXEDES FILHO, P. H. L.; MAGALHÃES, C. M. (2013). A neutralidade em audiodescrições de pinturas: resultados preliminares de uma descrição via teoria da avaliatividade. In: ARAÚJO, V. L. S.; ADERALDO, M. F. (Orgs.). Os novos rumos da pesquisa em audiodescrição no Brasil. 1ed. Curitiba: CRV, pp. 73-87.

PRAXEDES FILHO, P. H. L.; MAGALHÃES, C. M. (2015). Audiodescrições de pinturas são neutras? descrição de um pequeno corpus em português via sistema de avaliatividade. In: PONTES, V. O.; CUNHA, R. B.; CARVALHO, E. P.; TAVARES, M. G. G. (Orgs.). A tradução e suas interfaces: múltiplas perspectivas. Curitiba: CRV, pp. 99-130.

REMAEL, A.; VERCAUTEREN, G. (2007). Audio describing the exposition phase of films.Teaching students what to choose. TRANS. Revista de Traductología, Málaga, n. 11, pp. 73-93. 
SANTOS, S. A.; FARIAS JÚNIOR, L. R.; PRAXEDES FILHO, P. H. L. (no prelo). Tendência de assinatura avaliativa: um estudo de caso exploratório em roteiro de audiodescrição de peça de teatro.

SILVA, C. F.; PRAXEDES FILHO, P. H. L. (2014). A (in)existência de neutralidade: um estudo de caso baseado em corpus com roteiros de audiodescrições francesas de filmes via Teoria da Avaliatividade. Letras \& Letras. v. 30, n. 2, pp. 367-400.

SNYDER, J. (2008). Audio description: the visual made verbal. In: DIAZ-CINTAS, J. (Org.). The didactics of audiovisual translation. Amsterdã e Filadélfia: John Benjamins, pp. 191-198.

STANDARDS FOR AUDIO DESCRIPTION AND CODE OF PROFESSIONAL CONDUCT FOR DESCRIBERS. (2008). Disponível em: <https://www.nps.gov/ hfc/acquisition/pdf/audio-description/shared/attach-a.pdf $>$. Acesso em 04 abr 2016.

WHITE, P. (2003). Beyond modality and hedging: a dialogic view of the language of intersubjective stance. Text, v. 23, n. 2 (Special Edition on Appraisal), pp. 259-284.

Recebido: 19/05/2017

Aceito: 08/08/2017 